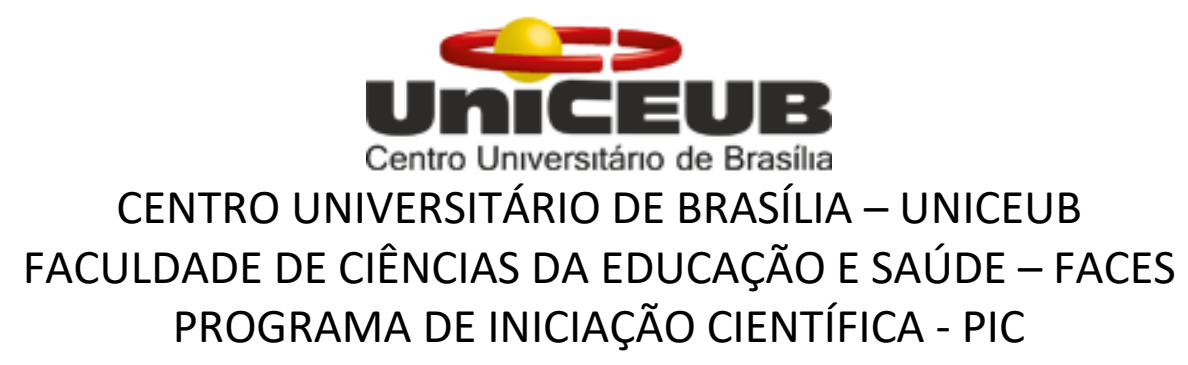

JOSÉ GOMES DO NASCIMENTO

CLEMENTE LUZ: O PRIMEIRO CRONISTA DE BRASÍLIA

BRASÍLIA

2017 


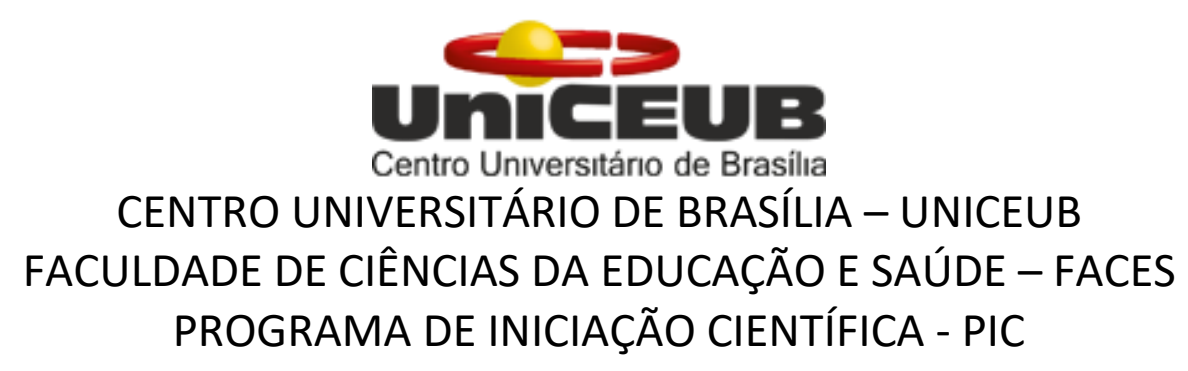

JOSÉ GOMES DO NASCIMENTO

\section{CLEMENTE LUZ: O PRIMEIRO CRONISTA DE BRASÍLIA}

Relatório final apresentado à Assessoria de PósGraduação e pesquisa pela Faculdade de Ciências da Educação e Saúde - FACES

Orientação: Prof. Dr. Rafael Voigt Leandro

BRASÍLIA 
De norte a sul, de leste a oeste, a agitação sentimental é imensa. O povo, com os olhos voltados para o ponto do mapa, onde a força do entusiasmo e do nacionalismo construiu uma cidade, aguarda o grande momento: a inauguração da Nova Capital da República. Os corações pulsam no ritmo novo, muito embora, a descrença habite alguns corações mal avisados ou maldoso. Desses corações que são alimentados pelo ódio e pelo desamor ao País. A batalha da construção chega ao fim. Pelo menos, a batalha da construção das obras essenciais e das instalações indispensáveis. E a fase, mais difícil, talvez, começa. Mais difícil, porque implica uma verdadeira revolução administrativa e doméstica. 


\title{
CLEMENTE LUZ: O PRIMEIRO CRONISTA DE BRASÍLIA
}

\author{
José Gomes do Nascimento - UniCEUB, PIBIC-CNPq, aluno bolsista. \\ Josegomes.14@hotmail.com
}

Rafael Voigt Leandro - UniCEUB, professor orientador

rafaelvoigt@gmail.com

Esta pesquisa buscou fazer um estudo da relação entre Jornalismo e Literatura, voltando-se para a análise das crônicas do trabalho jornalístico-literário do mineiro Clemente Luz (1920-1999) no período da construção de Brasília, sendo assim também, um dos primeiros literatos da nova capital. Diferentemente de outros grandes cronistas que ocupam ou ocuparam as páginas dos principais jornais do país, Clemente Luz não ocupou necessariamente a página jornalística, mas sim o espaço radiofônico da então recém-fundada Rádio Nacional de Brasília. Por meio das ondas do rádio, transmitia na hora do almoço suas crônicas para um número imenso de letrados e iletrados que circulavam pela capital ainda em construção. Já que a crônica, como gênero do discurso constitui um híbrido entre a literatura e o jornalismo, esse gênero textual representou um espaço para diversas abordagens a esse pioneiro das letras brasilienses, desde temas políticos a assuntos da vida cotidiana da então "capital da esperança". É um desses gêneros textuais em que a verdade e a ficção se misturam, para a representação da realidade, o que permite a verificação de como esse enunciado relativamente estável é resultado da relação da vida cotidiana em uma situação histórica específica. Clemente Luz toma para si, como matéria de suas crônicas, o cotidiano ainda em formação de uma cidade nascente. Suas crônicas radiofônicas foram reunidas anos depois pelo próprio autor no livro Invenção da Cidade (1967), que engloba textos produzidos entre 1958 até a inauguração de Brasília. Trata-se de obra pouco explorada até o momento, seja no campo dos estudos jornalísticos, seja na área dos estudos de literatura brasileira. Este projeto pretende recuperar do esquecimento histórico esse pequeno artefato de memória cultural, o que pode motivar novas discussões a respeito da narrativa histórica sobre os primeiros anos de Brasília. Os textos de Clemente Luz são analisados a partir dos estudos narrativos empreendidos por Mikhail Bakthin, teórico russo que contribui decisivamente para a compreensão, entre outros aspectos, de como os gêneros discursivos, como a crônica, são construções apoiadas em aspectos de interação social e histórica. De modo geral, este trabalho pretende investigar como Clemente Luz tomou para si a missão de produzir representações sobre a vida cotidiana da nova capital do Brasil e como sua atividade enunciativa transmite valores ideológicos, culturais e sociais, inerentes a esse processo histórico.

Palavras-Chave: Clemente Luz. Crônicas. Brasília. 


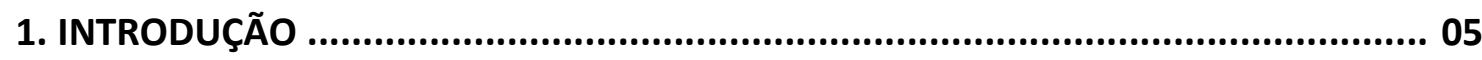

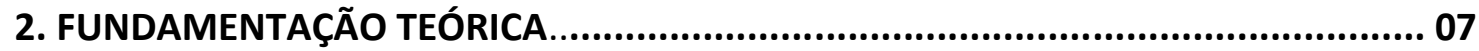

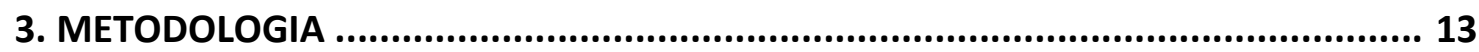

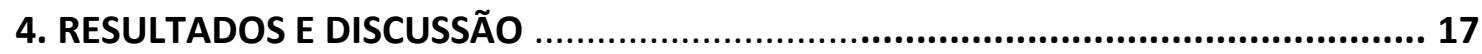

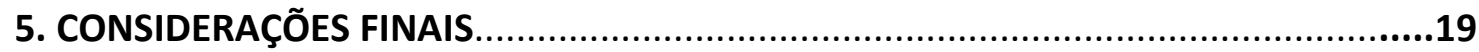

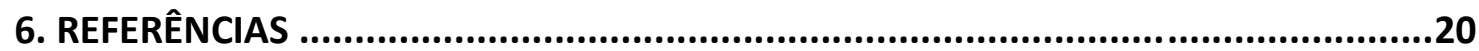

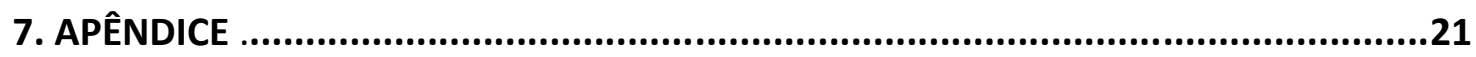





\section{INTRODUÇÃO}

Este trabalho trata da relação entre Jornalismo e Literatura, perpassando também pela História Cultural que cerca a construção de Brasília. Para tanto, a análise voltou-se para o trabalho jornalístico-literário de Clemente Luz (1920-1999), considerado um dos primeiros cronistas da nova capital. Como é sabido, o espaço jornalístico brasileiro dedicado às crônicas possui um número expressivo de bons cronistas, os quais ocupam ou ocuparam as páginas dos principais jornais do país. De Machado de Assis a Luís Fernando Veríssimo, a lista de cronistas brasileiros é imensa e de muita qualidade.

Mas é curioso que o objeto de análise desta pesquisa, o cronista Clemente Luz, não ocupou necessariamente a página jornalística, e sim, o espaço radiofônico da Rádio Nacional de Brasília, recém-fundada na cidade em construção em 1958. Era por intermédio das ondas do rádio que eram transmitidas as suas crônicas para um número imenso de letrados e iletrados que circulavam pela capital ainda em construção. Todos os dias na hora do almoço, uma crônica sua era lida, "com audiência compulsória e obrigatória nos acampamentos e nos refeitórios", como revela o próprio Clemente Luz em entrevistada concedida ao Arquivo Público do Distrito Federal - ArPDF. Audiência compulsória, muito devido aos alto-falantes instalados nos refeitórios dos acampamentos ou mesmo aos radinhos de pilha sincronizados por pioneiros para ouvir as crônicas, que eram muito bem lidas por Sérgio Dias e Rui Carneiro, locutores na época, da Rádio Nacional de Brasília. ${ }^{1}$

A rotina de leitura de crônicas na hora do almoço na construção durou de outubro de 1958 até 1961, período em que as crônicas foram suspensas porque o cronista saiu da Rádio por não simpatizar com o presidente Jânio Quadros, para onde voltou apenas em 1963.

Clemente Ribeiro da Luz nasceu no dia 29 de setembro de 1920 em uma fazenda chamada Quilombo, nas proximidades da Serra da Mantiqueira, município de Delfim Moreira (MG). Filho de Fernando da Costa luz e de Joaquina Ribeiro da Luz, vem de uma família humilde de lavradores, possuindo sete irmãos. Como revela nas orelhas de seus livros Invenção da cidade (1967) e Minivida (1972), e em entrevista oral², não teve uma vida fácil, já

\footnotetext{
${ }^{1}$ Antes de escrever as suas primeiras crônicas para a Rádio Nacional de Brasília, Clemente Luz já havia trabalhado na Rádio Guarani em Belo Horizonte, no qual ajudou na área de produção do primeiro jornal falado da cidade. Nessa época chegou a ensaiar algumas crônicas, mas nunca levadas a sério como as da nova capital.

${ }^{2}$ Concedida no ano de 1996 ao Arquivo Público do Distrito Federal - ArPDF.
} 
que vinha de uma família muito pobre e, por conta disso, só aos trancos e barrancos, conseguiu terminar os estudos aos 22 anos de idade.

Antes de acompanhar a construção de Brasília, atuou em jornais de Minas Gerais e Rio de Janeiro escreveu poesia (Ombros caídos, 1942). Além disso, de acordo Guimarães (2005), dedicou-se à literatura infantil, escrevendo entre outras obras: Bilino e Jaca, o mágico, 1944; Infância humilde de grandes homens, 1944; Aventura da bicharada, 1949; O caçador de mosquitos, 1953; Pedro Pipoca, 1957. Sua literatura infantil recebeu elogios, inclusive do cartunista Ziraldo que afirmou que "uma das leituras que mais gostara e que mais o impressionara quando criança foi O mágico (...)”. (GUIMARÃES, 2005, p. 284). Contudo, o que motivou esta pesquisa foi a transferência Clemente Luz como jornalista para a Rádio Nacional de uma Brasília, como o próprio cronista revela, "mais inventada do que construída em face da exiguidade do tempo".

As crônicas de Clemente Luz, foram reunidas anos depois pelo próprio autor, no livro Invenção da Cidade de 1967, que engloba textos produzidos entre 1958 até a inauguração de Brasília. Nesta pesquisa, seus escritos são analisados a partir dos estudos narrativos empreendidos pelo teórico russo Mikhail Bakthin (1997), que contribui decisivamente para a compreensão, entre outros aspectos, de como os gêneros discursivos, como a crônica, são construções apoiadas em aspectos de interação social e histórica.

Ao organizar Invenção da Cidade, Clemente Luz não modificou suas crônicas, preservando-Ihe a autenticidade e a espontaneidade. Surge desse fato a importância dessa obra para a história de Brasília, uma vez que o leitor tem o prazer de participar junto destes pioneiros da construção, ou melhor, da Invenção de Brasília, por meio das suas narrativas. Observando e analisando os discursos da obra de forma crítica, sem perder o lirismo espontâneo do cronista.

Tornou-se central a necessidade de investigar a reconstrução histórica do ambiente jornalístico dos primeiros anos do Distrito Federal e como as crônicas radiofônicas de Clemente representavam o ambiente vivenciado naquele período. Já que, como mencionado, a partir de 1958, Clemente teve suas crônicas veiculadas diariamente na Rádio Nacional.

A crônica, como gênero do discurso, constitui um híbrido entre a literatura e o jornalismo. Desde sua gênese constitutiva, esse gênero textual representou um espaço para abordagens diversas ao escritor-jornalista, de temas políticos a assuntos da vida cotidiana. É um desses gêneros textuais em que a verdade e a ficção se misturam, para a representação 
da realidade. Esse híbrido permite a verificação de como esse enunciado relativamente estável é resultado de um construto da vida cotidiana em uma situação histórica específica. Porém, mesmo diante dessa riqueza presentes no enunciado das suas crônicas, a obra de Clemente Luz, até o momento, ainda é pouco explorada, seja no campo dos estudos jornalístico, na área dos estudos de literatura brasileira ou historiografia.

Por conta disso, este trabalho busca investigar como Clemente Luz tomou para si a missão de produzir representações sobre a vida cotidiana da nova capital do Brasil e como sua atividade enunciativa transmite valores ideológicos, culturais e sociais, inerentes a esse processo histórico.

Além disso, mediante o objetivo principal acima, procuramos também: 1) discutir a fixação de balizas sobre o surgimento do jornalismo e da literatura brasiliense; 2) estudar as tendências literárias na crônica brasileira no tempo de Clemente Luz; 3) repensar a definição do gênero textual crônica a partir do estudo e análise do corpus de trabalho; 4) debater as relações entre memória, história e literatura, analisando o fenômeno de esquecimento na memória cultural de Brasília sobre a suas produções literárias pioneiras; 5) e discutir de que modo o discurso do cronista Clemente Luz fomenta a dialética das contradições sociais existentes no processo de instalação da nova Capital.

Por fim como produto final, almejamos produzir um artigo acadêmico, para apresentação em Congressos de Iniciação Científica, bem como para publicação em revista especializada, com o objetivo de difundir os resultados da pesquisa. A partir desse material, vislumbramos estimular, em alguma instância, a reedição das crônicas de Clemente Luz, para manutenção da memória cultural da cidade, assim como sensibilizar o público para olhar outros artefatos culturais abandonados, os quais são centrais para o imaginário e a invenção imagética de Brasília.

\section{FUNDAMENTAÇÃO TEÓRICA}

Sob o ponto de vista teórico, para possibilitar uma análise dos textos de Clemente Luz, esta pesquisa lançou mão, como citado, sobretudo dos estudos narrativos empreendidos por Mikhail Bakthin. O teórico russo desenvolveu sólidas análises sobre as várias vozes presentes no discurso (polifonia), a inter-relação entre os diversos discursos e textos (intertextualidade 
e dialogismo), bem como as diversas questões estéticas envolvendo narrativas complexas como a dos romances. Todas essas categorias puderam ser aproveitadas aqui para a compreensão do hibridismo narrativo da crônica do pioneiro das letras.

As crônicas, foram coligidas na obra Invenção da Cidade, lançada pelo jornalista em 1967. A opção de Clemente Luz pelo gênero literário-jornalístico crônica, estimulou na análise a inquietação de como a realidade passa pelo filtro de um gênero do discurso que tenta dar conta de uma representação do real, mas com a possibilidade do apelo estético próprio da linguagem literária.

Sendo assim, por esse meio de vinculação, como as crônicas de Clemente Luz alcançava um número significativo de ouvintes, permite, outrossim, observar um fenômeno raro de transmissão oral da literatura por meio do rádio, lembremos que esse é um significativo meio de comunicação para a difusão da entusiástica e utópica construção da "capital da esperança" para, sobretudo, os iletrados da nova capital, já que também existiam outros meios de comunicação dos estágios das obras da nova capital como a Revista Módulo, um dos meios de difusão da arquitetura e urbanismo de Brasília, que possuía nada mais nada menos que Oscar Niemeyer como fundador e diretor. Ademais, também havia a Revista Brasília, parte da Companhia Urbanizadora da Nova Capital - NOVACAP, que possuía circulação obrigatória para divulgar boletins informativos e, que por isso, foi criada em forma de revista com o objetivo, não apenas documentar, mas também defender a construção, a arquitetura e o urbanismo de

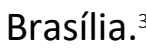

Isso posto, a literatura de Clemente Luz levanta o problema da crônica sob um viés histórico mais largo; como se, na invenção de uma cidade, a crônica servisse como o discurso inaugural, como os cronistas da época das grandes navegações. Entretanto, Clemente está na encruzilhada de servir ao público em sua função de comunicador social e de transmitir suas próprias percepções sobre a realidade, sem imparcialidade.

A crônica é um gênero discursivo. Como tal, constitui um enunciado construído historicamente, com características próprias e com função social específica. Essa concepção de gênero discursivo adentra o pensamento do teórico da linguagem Mikhail Bakhtin (1997).

Dentro dos estudos literários, a crônica recebeu tratamento de vários pesquisadores, interessados na definição desse gênero literário. É possível recuar no tempo e perceber a

\footnotetext{
${ }^{3}$ Cf. CAPPELLO, Maria Beatriz Camargo. A revista Brasília na construção da Nova Capital: Brasília (1957-1962). Risco: Revista de Pesquisa em Arquitetura e Urbanismo (Online), [S.I.], n. 11, p. 43-57, jan. 2010.
} 
crônica moderna vinculada à palavra grega cronos (tempo) bem como à crônica histórica (MOISÉS, 1985). Durante o período das grandes navegações, com a conquista de novos territórios, os cronistas-mor tiveram função de destaque para os relatos sobre a viagem.

A invenção da imprensa, também no século das grandes navegações, possibilita nova vida para a crônica, como relato de fatos cotidianos. Com a impressão diária do jornal, os cronistas se responsabilizam por destacar eventos sociais dos mais diversos, não sendo incomum, serem grandes escritores de sua época. Por muito tempo, e talvez até hoje, seja mesmo difícil dizer se uma crônica é puramente jornalística ou literária. É mais fácil compreendê-la como um gênero híbrido.

No Brasil, é inegável que a gênero "crônica" adquiriu um sentido mais diversificado a partir do século $X X$, muito em consequência do desenvolvimento do jornalismo no país. Nesse caso, muitos jornais passaram a publicar uma seção, na maioria das vezes diárias, na qual crônicas eram publicadas. De acordo com William V. Redmond (2010, p. 138), "em caráter de relato histórico, que é o significado tradicional pela sua etimologia e com uma nova roupagem, passou a ser usada com o sentido específico generalizado em literatura estritamente ligada ao jornalismo".

Dessa forma, os relatos e comentários de fatos do cotidiano presentes em seção de jornais (Correio da Manhã, Última Hora, Jornal do Brasil) tornaram a "crônica" parte integrante de suas páginas, contribuindo para que novas características surgissem nesse gênero do discurso. As crônicas passaram a ilustrar mais as incertezas, angústias, luta e as inquietações do ser humano no seu dia-a-dia. Para Redmond (2010, p. 138), "sob a atmosfera do Romantismo, o jornal cresceu no Brasil, o que contribuiu para o acento lírico predominar sobre a crônica, passando esta, a ser concebida como sinônimo de gênero literário, mantendo inter-relações com a prosa ou a poesia". Logo, a crônica, com breves comentários sobre algum fato do cotidiano, passa ser mais veiculado na imprensa, com finalidade utilitária e, com o objetivo de agradar aos leitores dentro de um espaço de mesma localização: o jornal.

De retorno a Bakthin (1997), em Estética da Criação Verbal, pode-se perceber a noção de hibridismo em nossas práticas comunicativas por meio de gêneros discursivos diversos. Bakhtin estuda o fenômeno cultural de cruzamento de várias manifestações linguísticas em um mesmo gênero discursivo, como, por exemplo, o romance. Por se inserirem plenamente na vida social, os gêneros, incluindo a crônica, absorvem diferentes dimensões da realidade, sem excluir os demais discursos que circulam ou circularam. 
Em conformidade com Bakthin (1997), os gêneros do discurso possuem uma infinita riqueza e variedade, resultante da própria variedade de atividades humanas que é inesgotável. Desta forma, cada esfera dessa atividade humana possui um repertório de gêneros do discurso que vai diversificando-se e ampliando-se à medida que dada esfera de atividade humana se desenvolve historicamente e fica mais complexa. Como consequência, os gêneros do discurso são compostos por uma heterogeneidade que reflete aspectos socioculturais e, conforme o autor,

Ficaríamos tentados a pensar que a diversidade dos gêneros do discurso é tamanha que não há e não poderia haver um terreno comum para seu estudo: com efeito, como colocar no mesmo terreno de estudo fenômenos tão díspares como a réplica cotidiana (que pode reduzir-se a uma única palavra) e o romance (em vários tomos), a ordem padronizada que é imperativa já por sua entonação e a obra lírica profundamente individual, etc.? A diversidade funcional parece tornar os traços comuns a todos os gêneros do discurso abstratos e inoperantes. (BAKHTIN, 1997, p. 280).

Quanto a essa diversidade, até os primeiros estudos de Bakhtin, esse problema não havia sido analisado adequadamente, pois conforme o próprio teórico, estudaram-se mais os gêneros literários, mas, na maioria das vezes pelo ângulo artístico-literário, e não enquanto tipos particulares de enunciados produzidos socialmente nas mais diferentes áreas do conhecimento e da atividade humana. No caso de Clemente Luz, podemos analisá-lo como o pioneiro/cronista, que vivia o dia-a-dia da construção de Brasília, e que por conta disso, possui nas suas crônicas um estilo individual que se relaciona de diversas maneiras com a língua comum da construção da futura capital, particularidade, que provavelmente outros poetas ou cronistas da época não dispunham, nesse caso Clemente Luz heterogeniza, ainda mais, o que se entendia por crônicas naquele período.

Ainda de acordo com Bakhtin (1997), é complicado minimizar essa heterogeneidade característica dos gêneros dos discursos e consequentemente há dificuldade de definição do caráter genérico do enunciado. Contudo, é notório considerar a diferença que existe entre o gênero de discurso primário (mais simples) e o gênero de discurso secundário (este mais complexo). Os gêneros secundários do discurso (o romance, o teatro, o discurso científico, o discurso ideológico, entre outros) aparecem em circunstâncias de uma comunicação cultural mais complexa, como a escrita artística, científica, sociopolítica. Durante o processo de formação dos gêneros secundários, existe uma absorção e transmutação dos gêneros mais simples, isto é, os primários (por exemplo, a conversa cotidiana em várias situações 
sociocomunicativas, no ambiente familiar, de trabalho, de lazer, etc.). Esse processo de construção dos gêneros secundários se dá de todas as espécies, constituindo-se em circunstâncias de uma comunicação verbal com maior cuidado na sua elaboração.

Para o teórico russo, o estudo da natureza do enunciado e da diversidade dos gêneros de enunciados nas diferentes esferas da atividade humana tem importância capital para todas as áreas da linguística e dos estudos literários. Portanto, se faz necessário possuir uma clara concepção da natureza do enunciado em geral e dos vários tipos de enunciados, sejam primários ou secundários. Por isso, os diversos gêneros do discurso são indispensáveis para qualquer estudo. Ignorar a natureza do enunciado e as particularidades do gênero do discurso - marcado pela variedade - leva ao formalismo e à abstração, desvirtua a historicidade do estudo e enfraquece o vínculo existente entre a língua e a vida. (BAKHTIN, 1997).

Nas análises das crônicas de Invenção da cidade, é de suma importância o entendimento da natureza do enunciado e da diversidade dos gêneros. Cabe lembrar que essas crônicas possuem uma relação com os gêneros simples, sejam eles um diálogo do cotidiano ou a carta de um pioneiro da construção de Brasília. Ter em mente a relação desses gêneros é importante para compreender o que se quer passar ao leitor, ou até mesmo, para compreender o mecanismo de interação com o mesmo. De acordo com Bakhtin (1997, p. 282), "a língua penetra na vida através dos enunciados concretos que a realizam, e é também através dos enunciados concretos que a vida penetra na língua. $O$ enunciado situa-se no cruzamento excepcionalmente importante de uma problemática". Clemente Luz, em Invenção da Cidade, capta a relação entre língua e vida do momento histórico de construção da nova capital.

O cronista se encontra nessa encruzilhada de narrar a vida desses pioneiros a partir da língua, utilizando-se justamente dos gêneros primários presentes na vida e no cotidiano da construção da futura capital. O que o torna Clemente Luz, que também era um pioneiro da construção de Brasília, o que o diferencia dos demais trabalhadores, é justamente a sua facilidade de transformar as situações cotidianas (lazer, alimentação, moradia, rotina de trabalho, expectativas e etc.) em linguagem escrita. Basta lembrar que as crônicas eram lidas na hora do almoço pelo locutor da Rádio Nacional de Brasília àqueles que eram os principais personagens das suas narrativas.

Ademais, Bakhtin (1997), em sua teoria sobre os gêneros do discurso, ocupa-se igualmente com o conceito de dialogismo. As práticas discursivas são um constante 
dialogismo e interacionismo. Surge daí os conceitos derivados como o de intertextualidade, em que se percebe como uma produção discursiva nunca é essencialmente genuína; constróise a partir de outros textos, quer seu autor tenha consciência desse fenômeno ou não.

Além disso, não podemos nos esquecer da tendência do jornalismo literário que recobrou fôlego a partir dos anos 1960, fruto de trabalhos destacados do novo jornalismo americano. Truman Capote, Tom Wolfe, Gay Talese, entre outros, são bons exemplos dessa tendência (PENA, 2006). Esses jornalistas estavam entre a ficção e a realidade, por meio de suas reportagens. Lança-se aqui a hipótese de que Clemente Luz estivesse praticando um certo jornalismo social, talvez próximo dessa corrente, mas com a preocupação de que textos curtos e objetivos, como a crônica, chegassem a um público amplo por meio da radiodifusão.

Até o momento, os trabalhos dedicados à literatura de Clemente Luz pouco contribuem para elucidar hipóteses como essas. Na verdade, encontra-se com maior frequência informações de Clemente em seu pioneirismo nas letras brasiliense, com dados biográfico e pouco análise de seus textos. É o que se pode verificar na obra História da literatura brasiliense, de Luiz Carlos Guimarães da Costa (2005).

Cruzam-se com obras como esta, preliminares, outras como $O$ capital da esperança (2008), de Gustavo Lins Ribeiro e Expresso Brasília (2012), de Edson Beú, que trazem à tona da discussão sobre a história de Brasília, um discurso contra-hegemônico sobre a construção da capital, sob a perspectiva da história do operariado, muitas vezes esquecidos pela historiografia oficial ou até mesmo preteridos pelos "maiorais de Brasília" como cita Clemente Luz, que são personagens como Lúcio Costa, Oscar Niemayer, Israel Pinheiro, Bernardo Sayão, sem mencionar o mais lembrado de todos: Juscelino Kubitschek. Esse cruzamento proporcionou a verificação do interesse de Clemente Luz por perspectiva semelhantes ainda na década de 1950 e 1960.

Não apenas as obras acima, como outras até mesmo de fontes fílmicas, entram em rota de colisão com o discurso oficial e hegemônico pertencente ou atribuídos a Juscelino Kubitschek (2000), como o do livro Por que construí Brasília. Essa dialética dos embates dos discursos auxilia na percepção de como o discurso literário-jornalístico de Clemente Luz situase entre esses dois pólos, num verdadeiro continuum discursivo sobre a nova capital. Inevitável aproveitar-se também de escritos do arquiteto Oscar Niemeyer, como Minha experiência em Brasília (1961), e de Lúcio Costa. Ambos, como projetistas do sentido de modernidade atribuído à nova capital, figuram como construtores de um discurso sobre 
urbanismo e a arte arquitetônica de Brasília, símbolos de uma construção e dimensão discursiva da cultura brasiliense.

É oportuna mencionar, ainda, a possibilidade de uma leitura comparativa das crônicas de Clemente Luz com a de outros cronistas que enfrentaram o tema Brasília como Clarice Lispector, em “Brasília" (1964) e "Brasília: esplendor" (1974), e Rachel de Queiroz, em "Brasília e a Rosa dos Ventos" (1988), presente no livro Obra Reunida (1989) da cronista; que justamente com outros cronistas da época, auxiliaram nesse processo. Já que de alguma maneira, o comparativismo auxilia no estudo de tendências discursivas da crônica brasileira (CANDIDO et al, 1992).

A partir dessas e de outras balizas teóricas, e literárias, pretendeu-se empreender a análise discursiva das crônicas de Clemente Luz na obra invenção da cidade.

\section{METODOLOGIA}

A metodologia desta pesquisa se pauta maiormente na revisão bibliográfica ampla. Com isso, em Metodologia científica, de Cervo, Bervian e Silva (2007), o método da pesquisa bibliográfica é definido da seguinte maneira. A pesquisa bibliográfica procura explicar um problema a partir de referências teóricas publicadas em artigos, livros, dissertações e teses. Os autores acrescentam ainda que, por esse método, se tem como objetivo indicar e verificar as contribuições existentes para a compreensão de determinado tema ou problema.

Por conta disso, optou-se, também neste estudo, pelo método qualitativo de pesquisa. Em consonância com Neves (1996), utilizamos métodos que se assemelham a procedimentos de interpretação dos fenômenos do cotidiano, muito devido a uma natureza comum destes procedimentos com aqueles que o pesquisador qualitativo emprega nas suas análises. Desta forma, a pesquisa qualitativa é constituída a partir de materiais que não receberam um tratamento analítico tão aprofundado - o caso do livro Invenção da cidade - ou que podem ser reexaminados com vistas a uma interpretação complementar ou até mesmo uma nova.

Como mencionado anteriormente, o objeto de estudo diz respeito à análise das crônicas de Clemente Luz escritas de 1958 à inauguração de Brasília. Mas, como essas crônicas foram reunidas - ele não as modificou, preservando-Ihe a autenticidade e a espontaneidade anos depois na obra Invenção da cidade (1967), esta, se tonou a nossa fonte principal. 
Na primeira etapa desse percurso, a revisão de literatura convém como estratégia para explorar não somente o corpus de análise centrado em obra única de Clemente Luz, mas os desdobramentos e o dialogismo existente entre sua obra e a de outros cronistas da época, que podem ter relatado os primeiros tempos de Brasília. Nesse caso, a obra História da literatura brasiliense, de Luiz Carlos Guimarães da Costa (2005) serviu como mote para iniciar as análises sobre outros cronistas dos primeiros anos da nova capital, contudo a publicação só confirmou o fato de que Clemente Luz foi o pioneiro dos pioneiros, sendo o primeiro cronista de Brasília. Muito devido ao fato de ter sido também o primeiro jornalista profissional instalado em Brasília, reafirmando a estreita relação entre o jornalismo e o gênero crônica. Como confidencia em depoimento ao ArPDF: “(...) profissionalmente, o primeiro jornalista que se instalou em Brasília fui eu. Que eu além de trabalhar pra Rádio Nacional, eu tinha uma correspondência com a Agência Meridional dos Diários Associados e com a Agência Nacional do governo." (LUZ, 1996, p. 7).

Além dessa revisão aproximada ao corpus, coube também um levantamento bibliográfico acerca de questões teóricas e históricas de alto relevo. Como a teoria narrativa bakhtiniana serviu como método de leitura literária crítica da obra de Clemente Luz, foi imprescindível que, a partir do levantamento inicial, o aprofundamento da visão sobre esse campo dos estudos literária para a percepção de como os discursos revelam ideologias de diversos matizes, históricos, políticos e socioeconômicos, por exemplo; especialmente no contexto daquele período histórico em que as crônicas são produzidas.

Além disso, em outra etapa, foi de muita importância fazer uma biografia do cronista Clemente Luz, nesse caso estabeleceu-se uma pesquisa em sites, blogs, jornais de época - a partir da Hemeroteca Digital da Biblioteca Nacional; e, também novamente na obra História da literatura brasiliense (2005), que traz uma pequena biografia e depoimentos a respeito do cronista. Além disso, os próprios livros do autor Invenção da cidade (1967) e Minivida (1972), carregam em suas orelhas pequenas estórias da vida de Clemente Luz, contadas por ele mesmo.

Contudo, ainda sim diante da quase falta de informações sobre esse pioneiro das letras da nova capital e mesmo com as pesquisas acima, ainda restavam muitas lacunas sobre a vida do cronista. Algumas perguntas ainda continuavam sem respostas, como: Clemente começou seu trabalho jornalístico de escrever crônicas em Brasília? Já possuía experiência com a escrita, para ter sido escolhido para ser o cronista da cidade? Como chegou em Brasília e 
conseguiu o emprego na então recém-fundada Rádio nacional da cidade? O que mais exerceu em Brasília além escrever crônicas? O que fez após a inauguração da cidade? Perguntas não faltavam e as biografias encontradas não supriam tais indagações. Diante dessa problemática biográfica, nos confortamos ao encontrar no Arquivo Público do Distrito Federal ${ }^{4}$ uma importante fonte que respondiam nossas indagações, um Relato Oral, feito com Clemente Luz em 1996. Parte do Programa de História Oral do ArPDF, na Linha de Pesquisa Memória da Construção de Brasília, o relato ajudou a conhecer melhor o cronista, e com isso, compreender melhor por meio da relação entre "escrita e vida do autor", o que Luz procurava transmitir com as suas crônicas diárias.

Nesse sentido, ter disponíveis diversas fontes, que perpassam por diferentes áreas do conhecimento: como documentos oficiais, relatos orais, iconografias, materiais audiovisuais, entre outros, ajuda e muito a tarefa de pesquisadores de narrar a história de Brasília por outros vieses. No caso é esse o trabalho do ArPDF, que auxilia e disponibiliza fontes com temáticas diversas para a realização de pesquisas. O ArPDF é aberto ao público e as solicitações de consulta ao acervo podem ser feitas pessoalmente e à distância também. ${ }^{5}$

Posto isso, por meio da História Oral, a revisão histórica foi um convite para revisitar a literatura canônica e não canônica sobre a história de construção e fundação de Brasília, com um processo de seleção de obras das mais diversas, capazes de servirem, dialeticamente, como ponto de confronto com o discurso literário-jornalístico de Clemente Luz, complementado pelo fato de que a área de formação do estudante é História, com outros trabalhos realizados sobre Brasília.

Após conhecer o cronista, foi necessário compreender a organização de sua obra Invenção da cidade (1967) de uma forma não apenas macro como também micro. Nesse caso, além da leitura das crônicas presentes no livro, foi observado e sistematizado como a obra foi dividida e porquê. Além disso, tornou-se essencial conhecer os capítulos (o cronista chama de

\footnotetext{
${ }^{4}$ O ArPDF foi criado em 1985 por meio do decreto 8.530, vinculado na época à Secretaria de Educação e Cultura do DF, tendo como objetivo principal guardar uma memória que não poderia se perder: a história de Brasília. Desde os primórdios da cidade, foi constatado que era imprescindível recolher, preservar e garantir uma proteção especial a documentos arquivísticos de imenso valor para a memória histórica do Distrito Federal, acumulados pela a administração tanto direta quanto indireta do DF. (ARPDF, 2015).

${ }^{5} \mathrm{O}$ acervo do arquivo é composto por material textual (registros funcionais e de despesas, livros de atas e ocorrências, decretos, recortes de jornais, dentre outros), plantas arquitetônicas, fotografias, filmes, folhetos, cartazes, periódicos, coleção depositária, depoimentos orais e material bibliográfico. Este rico acervo compõe um cenário de relevância sem igual para pesquisas sobre a história de Brasília e do Distrito Federal, mas, infelizmente ainda é relativamente pouco utilizado.
} 
livros) e suas subdivisões. Analisar as temáticas e focos narrativos das crônicas dessas partes do livro foi importante para compreender como o cronista guiou as leituras dos seus leitores sobre a história da "invenção de Brasília".

Outro aspecto significativo foi considerar, por meio das teorias de Bakhitin, que Clemente Luz se insere em uma tradição da crônica brasileira, podendo, direta ou indiretamente, ter criado um diálogo com cronistas de outros veículos de comunicação que escreveram sobre os primeiros tempos de Brasília. Mas além disso, por conta de seu estilo ímpar, analisar o panorama também da crônica brasileira década de 1950 e 1960 foi importante para descobrir as tendências literárias na crônica brasileira no tempo de Clemente Luz.

Dessa forma, a partir de algumas obras, especialmente "As cem melhores crônicas brasileiras" (2007), organizado por Joaquim Ferreira dos Santos, foi possível realizar a produção de um texto a respeito dos grandes cronistas da época de Clemente Luz, tais como: Carlos Drummond de Andrade, Rubem Braga, Sérgio Porto, Rachel de Queiroz... e se esses(as) cronistas também escreveram sobre Brasília. Além disso, por meio das crônicas desses sujeitos, foi analisado se os mesmos, podem ter influenciado o trabalho de Clemente Luz.

Por fim, foi feita efetivamente a análise das crônicas de Invenção da cidade, utilizandose muito também de outros conhecimentos produzidos, acima mencionados, observando nos discursos de Clemente Luz se havia ambivalências, fossem nos seus personagens ou nas situações apresentadas (mais pobres, grandes expoentes, discurso de desenvolvimentismo e interiorização). Para isso, foi necessária uma revisão bibliográfica de algumas obras que tratassem também de análise literária, tais como: personagens, foco narrativo, linguagem e ideologia, entre outras; além da teoria dos gêneros dos discursos de Bakhtin.

Durante a pesquisa, teve-se o cuidado ao longo desse processo de construção de conhecimentos, de que o aluno-pesquisador registrasse, de modo organizado, a memória de suas leituras por meio de fichamentos, resenhas e, principalmente, sistematizações. Todo esse gênero textual compõe o que se chama de diário de pesquisa, um importante auxiliar do processo de pesquisa (MACHADO, LOUSA, ABREU-TARDELLI, 2005). Destarte, esses registros subsidiaram a produção de um artigo científico, facilitando a confecção do produto final desta pesquisa. 


\section{RESULTADOS E DISCUSSÃO}

Os registros da pesquisa, resultantes das produções realizadas por meio da metodologia descrita acima, foi composto pelas seguintes sistematizações e resenha (ver apêndice): A) Mikhail Bakhtin e os gêneros do discurso, sistematização que apresenta a relação dos gêneros do discurso com as crônicas de Clemente Luz; B) Biografia do cronista Clemente Ribeiro da Luz, sistematização que faz um estudo da vida do primeiro cronista de Brasília; C) Resenha do livro Invenção da Cidade de Clemente Luz (1967), que analisa a obra em que cronista reuniu as suas crônicas; D) O panorama da crônica brasileira na década de 1950 e 1960, sistematização que trabalha as tendências literárias na crônica brasileira no tempo de Clemente Luz; E) Análise das crônicas de Invenção da cidade, sistematização que trabalha a análise da crônicas de Clemente Luz. Esses estudos foram feitos em linguagem e formatação a fim de facilitar a produção de um artigo final.

Dessa forma, o produto final da pesquisa, como mencionado, consiste em um artigo científico, realizado mediante os conhecimentos produzidos e documentados ao longo de um ano. Esse produto proporcionou ao aluno-pesquisador compreender que, por meio desse gênero textual, pode-se socializar o conhecimento produzido para a comunidade acadêmica. Além disso, o artigo suscitou por consequência, o amadurecimento acadêmico do aluno pesquisador, como exercícios para se estruturar um artigo (identificação, resumo, palavrachave, situação-problema, discussão, solução-avaliação, referências, anexos), bem como da linguagem mais adequada para a efetivação desse trabalho.

Outro aspecto importante dos resultados obtidos na pesquisa além da produção dos materiais mencionados diz respeito a qualidade e riqueza de discussões nas reuniões e encontros ao longo da pesquisa, onde troca de experiências e debates teóricos proporcionaram um imenso enriquecimento acadêmico aos agentes do trabalho de pesquisa. Além disso, esses fatos marcantes só contribuíram para a confirmação de que o primeiro cronista de Brasília e sua obra Invenção da cidade, precisa ser mais conhecido pelos amantes da literatura e da nova capital do Brasil, para que não caia (ainda) mais no esquecimento.

Por conta do tempo e da dificuldade na busca de referências sobre o Clemente Luz e a literatura brasiliense, não conseguimos, como traçados nos objetivos iniciais do projeto, mapear e inventariar as primeiras crônicas sobre Brasília, produzidas por Clemente Luz e 
outros cronistas, para composição de um catálogo, a ser anexado ao artigo acadêmico produzido ao final do projeto; e também, retratar parte da história da comunicação social regional durante o período de construção de Brasília. Contudo, esses objetivos podem ser alcançados em uma pesquisa futura, que complementaria esta apresentada e, que já teria como suporte, o artigo científico resultante desta etapa. Nesse caso, as duas etapas da pesquisa fariam com que os resultados da pesquisa fossem divulgados e distribuídos para instituições culturais da cidade (Secretaria de Cultura, Arquivo do DF, Biblioteca Nacional de Brasília...), a fim de contribuir para a preservação da memória literária brasiliense, também (ainda) não contemplado nesse primeiro momento.

Ademais, com artigo acadêmico já finalizado, buscaremos agora fazer a sua apresentação em Congressos de Iniciação Científica, bem como publicar em revista especializada, com o objetivo de difundir os resultados da pesquisa.

Aliás, com os conhecimentos produzidos, buscaremos ainda também estimular, em alguma instância, a reedição das crônicas de Clemente Luz, para manutenção da memória cultural da cidade, assim como sensibilizar o público para olhar outros artefatos culturais abandonados, os quais são centrais para o imaginário e a invenção imagética de Brasília. Já que, a releitura e análise das primeiras crônicas sobre Brasília, produzidas, em particular, por Clemente Luz, representam uma contribuição inconteste para a memória cultural da cidade, sendo uma forma de contar a história da cidade através da literatura.

Isso posto, memória cultural representada pelas crônicas de Clemente Luz traz à tona não somente a exaltação quase ufanista da nova capital, mas também acompanha os passos daqueles que emprestaram sua força para a erguimento de monumentos e prédios - os candangos e os primeiros brasilienses -, responsáveis por uma dessas odisseias raras e de espelhamento de um país que se pretendia moderno, com uma capital planejada a partir de projetos urbanísticos e arquitetônicos de relevo, uma "marco" não apenas para o Brasil como também para o mundo.

Por conseguinte, a partir dos resultados obtidos, a pesquisa pretende recuperar da poeira do esquecimento (ou do silenciamento) histórico esse pequeno artefato de memória cultural que são as crônicas presentes em Invenção da cidade (1967), o que pode motivar novas discussões a respeito da narrativa histórica sobre os primeiros anos de Brasília. 


\section{CONSIDERAÇÕES FINAIS}

Este trabalho procurou investigar como Clemente Luz tomou para si a missão de produzir representações sobre a vida cotidiana de Brasília durante a sua construção e como sua atividade enunciativa transmite valores ideológicos, culturais e sociais, relacionadas a esse processo histórico nas suas crônicas diárias, reunidas em Invenção da cidade (1967).

A análise documental e revisão bibliográfica mostrou que a literatura de Clemente Luz levanta o problema da crônica sob um viés histórico mais largo; como se, na invenção de uma cidade, a crônica servisse como o discurso inaugural. Mas, nesse discurso Clemente Luz se encontrou numa encruzilhada de servir ao público em sua função de comunicador social na Rádio Nacional de Brasília, mas também de transmitir as suas próprias percepções sobre a realidade em que também estava inserido, sem ser imparcial como demonstraram algumas das suas crônicas.

Assim, a invenção da cidade, Brasília, se faz de jornalismo e literatura, esta vinda de uma relação estreita. É uma evidência de que a construção de uma nova cidade (cidadecapital) é também a construção de um discurso, ou de trocas simbólicas e culturais capazes de trazer o "Brasil Moderno", a princípio, aparentemente só há barro vermelho, poeira... também para as letras de quem também vivenciava o momento histórico.

A memória cultural representada pelas crônicas de Clemente Luz traz à tona não somente a exaltação quase ufanista e utópica da nova capital, mas também acompanha os passos dos mais pobres e muitas vezes esquecido pela historiografia oficial de Brasília, que emprestaram sua força para que se construísse a "capital da esperança" no país que se pretendia moderno, com uma nova cidade-capital planejada a partir de projetos urbanísticos e arquitetônicos movido pela racionalidade.

Logo, as narrativas de Clemente Luz apresentam diversas contradições nacionais inerentes ao processo de transferência e fundação de uma nova capital, de um novo centro político da nação. De mais a mais, o cronista Clemente Luz demonstra o poder da escrita, entre jornalismo e literatura, como palco político de diversos anseios sociais, de esperança, de renovação, de novos tempos para a nação brasileira.

Contudo, mesmo com Clemente Luz utilizando, como matéria de suas crônicas, o cotidiano ainda em formação de uma cidade nascente, sua obra ainda é pouco explorada, seja no campo dos estudos jornalístico, seja na área dos estudos de literatura brasileira ou como 
fonte para historiografia brasiliense. Por conta disso esse projeto além de recuperar da poeira do esquecimento esse pequeno artefato de memória cultural que são as suas crônicas, procura também possibilitar o surgimento de novas pesquisas e abordagens acerca de Clemente Luz e sua obra, do surgimento da literatura Brasiliense e até mesmo de outras obras contra-hegemônicas da história de Brasília.

\section{REFERÊNCIAS}

ARQUIVO Público do Distrito Federal. Guia [do] Arquivo Público do Distrito Federal. Brasília: O Arquivo, 2015.

BAKHTIN, Mikhail M. Os gêneros do discurso. In: . Estética da criação verbal. Tradução feita a partir do francês por Maria Emsantina Galvão G. Pereira. 2o Ed, São Paulo: Martins Fontes, 1997.

BEÚ, Edson. Expresso Brasília: a história contada pelos candangos Brasília: Ed. UnB, 2012.

CAPPELLO, Maria Beatriz Camargo. A revista Brasília na construção da Nova Capital: Brasília (1957-1962). Risco: Revista de Pesquisa em Arquitetura e Urbanismo (Online), [S.I.], n. 11, p. 43-57, jan. 2010.

CANDIDO, A. et al. A crônica: o gênero, sua fixação e suas transformações no Brasil. Campinas, SP: Ed. da Unicamp; Rio de Janeiro: Fundação Casa de Rui Barbosa, 1992.

CERVO, Amado L.; BERVIAN, Pedro A.; SILVA, Roberto da. Metodologia Científica. 6a ed. São Paulo: Pearson Prentice. Hall, 2007.

COSTA, Lúcio. Brasília, cidade que inventei. Brasília: Iphan, 2014.

COSTA, Luiz Carlos Guimarães da. História da literatura brasiliense. Brasília: Thesaurus, 2005.

KUBITSCHEK, Juscelino. Por que construí Brasília. Brasília: Senado Federal, 2000.

LISPECTOR, Clarice. Visão do esplendor. Rio de Janeiro: Francisco Alves, 1975.

LUZ, Clemente Ribeiro da. A invenção da cidade. Apresentação de Juscelino Kubitschek; prefácio de Israel Pinheiro. DF: Editora Horizonte - EBRASA, 1967.

Federal, 1996.

. Depoimento - Programa de História Oral. Brasília, Arquivo Público do Distrito

. Minivida. DF: EDIPLAN, 1972.

MACHADO, Anna Rachel; LOUSADA, Eliane; ABREU-TARDELLI, Lília Santos. Planejar gêneros acadêmicos. São Paulo: Parábola Editorial, 2005. 
MOISÉS, Massaud. A criação literária: prosa. 12. ed. São Paulo: Cultrix, 1985.

NEVES, José Luis. Pesquisa qualitativa - características, usos e possibilidades. Cadernos de pesquisa em administração, São Paulo, vol. 1, no 3, $2^{\circ}$ Sem./1996.

NIEMEYER, Oscar. Minha experiência em Brasília. Brasília: Ed. Vitória, 1961.

PENA, Felipe. Jornalismo literário. São Paulo: Contexto, 2006.

QUEIROZ, Rachel de. Obra Reunida. Vol.5. Rio de Janeiro: José Olympio, 1989.

REDMOND, William Valentine. Aspectos da crônica no Brasil: uma reflexão crítica. Juiz de Fora: CES/JF, v. 9, n. 17. p.133-142, jan./jun. 2010.

RIBEIRO, Gustavo Lins. O capital da esperança: a experiência dos trabalhadores na construção de Brasília. Brasília: UnB, 2008.

SANTOS, Joaquim Ferreira dos (Org.). As cem melhores crônicas brasileiras. Rio de Janeiro: Objetiva, 2007.

\section{APÊNDICE A: SISTEMATIZAÇÕES E RESENHA}

\section{Mikhail Bakhtin e os gêneros do discurso}

O pesquisador, filósofo, pensador e teórico russo Mikhail Mikhailovich Bakhtin (18951975) foi uma das figuras mais importantes para o estudo da linguagem verbal. Cabe ressaltar que suas produções entre os anos 1920 e 1974, gerados nos vários e produtivos Círculos de discussão e construção de uma postura ímpar em relação à linguagem e seus estudos, têm forte impacto na teoria literária e na linguística.

O livro Estética da criação verbal foi publicado em Moscou no ano de 1979 pelas Edições Iskustvo, quatro anos após a morte de Bakhtin. O livro é composto por vários textos escritos em momentos distintos encontrado nos seus arquivos. O texto "Os gêneros do discurso", escrito entre 1951 e 1953, aparece na última parte do livro, intitulada "Adendo", que também é composto por cinco outros textos. Em conformidade com Sobral (2009), o texto mencionado consistia num esboço prévio de um livro sobre o assunto que Mikahail Bakhtin pretendia escrever mais sobre. Assim sendo, o texto está dividido em duas partes: "O 
problema e sua definição" e "O enunciado como unidade de comunicação discursiva: diferença entre essa unidade e as unidades da língua (palavras e orações)".

Em “Os gêneros do discurso", Mikhail Bakhtin (1997) destaca que, em todas as esferas da atividade humana, há sempre a utilização da língua, sendo esta de caráter e modos variados. Desta forma, os enunciados - sejam eles orais ou escritos - são a forma pela qual uma determinada atividade humana se utiliza das funções da linguagem. O enunciado é composto por três elementos: o conteúdo, o estilo e sua construção composicional. Estes elementos fundem-se no enunciado, sendo marcados pela peculiaridade de uma esfera da comunicação. Para Bakhtin (1997, p. 180) todo enunciado isolado é individual, porém, "cada esfera de utilização da língua elabora seus tipos relativamente estáveis de enunciados".

Os gêneros do discurso possuem uma riqueza e, sobretudo, variedade, que é infinita. Isso se dá pelo fato de que a própria variedade de atividades humanas é inesgotável. Isto é, cada esfera dessa atividade humana possui um repertório de gêneros do discurso que vai diversificando-se e ampliando-se à medida que dada esfera de atividade humana se desenvolve historicamente e fica mais complexa. Assim, os gêneros do discurso são compostos por uma heterogeneidade que reflete aspectos socioculturais, desde um diálogo cotidiano, passando por uma carta (ou atualmente o e-mail), até todo universo de declarações públicas (ofícios, memorandos, pronunciamentos). Por conta disso, conforme o autor,

Ficaríamos tentados a pensar que a diversidade dos gêneros do discurso é tamanha que não há e não poderia haver um terreno comum para seu estudo: com efeito, como colocar no mesmo terreno de estudo fenômenos tão díspares como a réplica cotidiana (que pode reduzir-se a uma única palavra) e o romance (em vários tomos), a ordem padronizada que é imperativa já por sua entonação e a obra lírica profundamente individual, etc.? A diversidade funcional parece tornar os traços comuns a todos os gêneros do discurso abstratos e inoperantes. (BAKHTIN, 1997, p. 280).

A partir desse argumento referente à diversidade funcional dos gêneros do discurso, esse problema nunca tenha sido analisado adequadamente até os primeiros estudos de Bakhtin. Estudaram-se mais os gêneros literários, porém, na maioria das vezes pelo ângulo artístico-literário, e não enquanto tipos peculiares de enunciados produzidos socialmente nas mais diferentes áreas do conhecimento e da atividade humana. [Tentar associar "atividade humana" à profissão de Clemente Luz]

Para Bakhtin (1997), é complicado minimizar essa heterogeneidade característica dos gêneros dos discursos e consequentemente a dificuldade de definição do caráter genérico do 
enunciado. Porém, é importante levar em consideração a diferença essencial que existe entre o gênero de discurso primário (este o mais simples) e o gênero de discurso secundário (este mais complexo).

Desta forma, os gêneros secundários do discurso (o romance, o teatro, o discurso científico, o discurso ideológico, entre outros) aparecem em circunstâncias de uma comunicação cultural mais complexa, como a escrita artística, científica, sociopolítica. Isso ocorre pelo fato de que, durante o processo de formação dos gêneros secundários, existe uma absorção e transmutação dos gêneros mais simples, isto é, os primários (por exemplo, a conversa cotidiana em várias situações sociocomunicativas, no ambiente familiar, de trabalho, de lazer, etc.). Esse processo de construção dos gêneros secundários se dá de todas as espécies, constituindo-se em circunstâncias de uma comunicação verbal com maior cuidado na elaboração.

Quanto aos gêneros primários, ao se tornarem componentes dos gêneros secundários, transformam-se dentro destes e adquirem uma característica particular: perdem sua relação imediata com a realidade existente e com a espontaneidade dos enunciados cotidianos. Logo, a crônica - nosso objeto de análise - pode ser considerada um gênero secundário, pois se utiliza muitas das vezes de gêneros primários para narrar um acontecimento do cotidiano. Mas com base em Bakhtin, tanto a crônica como a réplica do cotidiano são enunciados; o que diferença os dois é o fato de que a primeira é um enunciado secundário, ou seja, complexo, justamente pelo fato de que se utiliza da segunda, que, nesse contexto, perde a sua relação imediata com a realidade existente. Para Bakhtin (1997, p. 281-282)

(...) a distinção entre gêneros primários e gêneros secundários tem grande importância teórica, sendo esta a razão pela qual a natureza do enunciado deve ser elucidada e definida por uma análise de ambos os gêneros. Só com esta condição a análise se adequaria à natureza complexa e sutil do enunciado e abrangeria seus aspectos essenciais.

A inter-relação entre os gêneros primários e secundários de um lado, o processo histórico de formação dos gêneros secundários do outro, é o melhor caminho para esclarecer a natureza do enunciado e, acima de tudo, o problema da correlação entre língua, ideologias e visões do mundo.

O estudo da natureza do enunciado e da diversidade dos gêneros de enunciados nas diferentes esferas da atividade humana tem importância capital para todas as áreas da linguística e dos estudos literários. Para Bakhtin isso se dá pelo fato de que

[...] um trabalho de pesquisa acerca de um material linguístico concreto - a história da língua, a gramática normativa, a elaboração de um tipo de dicionário, a estilística 
da língua, etc. - lida inevitavelmente com enunciados concretos (escritos e orais), que se relacionam com as diferentes esferas da atividade e da comunicação: crônicas, contratos, textos legislativos, documentos oficiais e outros, escritos literários, científicos e ideológicos, cartas oficiais ou pessoais, réplicas do diálogo cotidiano em toda a sua diversidade formal, etc. É deles que os pesquisadores extraem os fatos linguísticos de que necessitam. Uma concepção clara da natureza do enunciado em geral e dos vários tipos de enunciados em particular (primários e secundários), ou seja, dos diversos gêneros do discurso, é indispensável para qualquer estudo, seja qual for a sua orientação específica. (BAKHTIN, 1997, p. 282).

Conforme o trecho acima, ignorar a natureza do enunciado e as particularidades do gênero do discurso - marcado pela variedade - leva ao formalismo e à abstração, desvirtua a historicidade do estudo e enfraquece o vínculo existente entre a língua e a vida.

Sendo assim, nas análises das crônicas do livro Invenção da cidade, de Clemente Luz, é de suma importância o entendimento da natureza do enunciado e da diversidade dos gêneros. É importante lembrar que essas crônicas possuem uma relação com os gêneros simples, sejam eles um diálogo do cotidiano ou a carta de um pioneiro da construção de Brasília. Ter em mente a relação desses gêneros é importante para compreender o que se quer passar ao leitor, ou até mesmo, para compreender o mecanismo de interação com o mesmo. O cronista Clemente Luz, em Invenção da Cidade, capta a relação entre língua e vida do momento histórico de construção da nova capital. De acordo com Bakhtin (1997, p. 282), "a língua penetra na vida através dos enunciados concretos que a realizam, e é também através dos enunciados concretos que a vida penetra na língua. O enunciado situa-se no cruzamento excepcionalmente importante de uma problemática".

Clemente Luz encontra-se nessa encruzilhada de narrar a vida desses pioneiros a partir da língua, se utilizando justamente dos gêneros presentes na vida e no cotidiano da construção da futura capital, ou seja, os gêneros primários. O cronista conhece o teor de várias cartas, pois também era escriba nesse período. Sabe das expectativas para com a cidade, pois era um pioneiro igual aos outros. Compreende a situação da alimentação, do lazer, da moradia e da saúde, uma vez que também precisava e participava dessas situações. Em outras palavras, o que o torna diferente dos demais trabalhadores é justamente a sua facilidade de transformar todas essas situações cotidianas em linguagem escrita. Sendo que elas eram lidas na hora do almoço pelo locutor da Rádio Nacional de Brasília àqueles que eram os principais personagens das suas narrativas simplistas.

Bakhtin (1997) também aborda alguns pontos da linguística. Para o autor, o estilo está indissoluvelmente ligado ao enunciado e a formas típicas de enunciados, isto é, aos gêneros do discurso. O enunciado - oral e escrito, primário e secundário, em qualquer esfera da 
comunicação verbal - é individual, e por isso pode refletir a individualidade de quem fala ou escreve. Cada um possui um estilo individual. Clemente Luz possui o seu estilo. Preza por uma linguagem simples, muito por conta dos seus leitores, ou melhor, ouvintes, candangos que na sua grande maioria possuíam pouco estudo. Além disso, possui uma variedade de abordagens que dá a entender que era bem atento ao que acontecia ao seu redor, nesse caso a construção do símbolo do desenvolvimento e da integração do Brasil na década de 1960. Talvez entre nessa conta também o fato de ele ter sido também um candango e de vir de um contexto humilde. Mas é fato que ele possui o seu estilo, estilo esse que prende o leitor nas suas narrativas. Segundo Bakhtin (1997), nem todos os gêneros são igualmente aptos para refletir a individualidade na língua do enunciado, isto é, nem todos são propícios ao estilo individual. Os mais propícios são os literários; se bem que, nesse âmbito, a diversidade dos gêneros oferece uma ampla gama de possibilidades variadas de expressão à individualidade, provendo a diversidade de suas necessidades. As condições menos favoráveis para refletir a individualidade consiste nas oferecidas pelos gêneros do discurso que requerem uma forma padronizada, como a formulação do documento oficial, da ordem militar, da nota e serviço, etc.

Vale destacar que os gêneros do discurso podem revelar a variedade dos estratos e dos aspectos da personalidade individual. O estilo individual pode relacionar-se de diferentes maneiras com a língua comum. Como mencionado, o estilo do Clemente Luz revela que ele também estava inserido na linguagem desenvolvimentista do período da construção de Brasília. Por vezes deixa transparecer nas suas crônicas o caráter místico da cidade, que vem desde a visão de Dom Bosco. O cronista também estava inserido naquele pensamento de que Brasília seria a capital da esperança e mudaria os rumos do país.

Para Bakhtin (1997, p. 283), porém, “o problema de saber o que na língua cabe respectivamente ao uso corrente e ao indivíduo é justamente problema do enunciado, apenas no enunciado a língua comum se encarna numa forma individual". Nesse caso, a definição de um estilo geral ou individual requer um estudo aprofundado do que já foi mencionado, ou seja, da natureza do enunciado e da diversidade dos gêneros do discurso.

O filósofo russo menciona que o vínculo indissolúvel, orgânico, entre o estilo e o gênero mostra-se claro quando se trata do problema de um estilo linguístico ou funcional. Para Bakhtin, o estilo linguístico ou funcional nada mais é que "um estilo de um gênero peculiar a uma dada esfera da atividade e da comunicação humana". Para ele, 
Cada esfera conhece seus gêneros, apropriados à sua especificidade, aos quais correspondem determinados estilos. Uma dada função (científica, técnica, ideológica, oficial, cotidiana) e dadas condições, específicas para cada uma das esferas da comunicação verbal, geram um dado gênero, ou seja, um dado tipo de enunciado, relativamente estável do ponto de vista temático, composicional e estilístico. O estilo é indissociavelmente vinculado a unidades temáticas determinadas e, o que é particularmente importante, a unidades composicionais: tipo de estruturação e de conclusão de um todo, tipo de relação entre o locutor e os outros parceiros da comunicação verbal (relação com o ouvinte, ou com o leitor, com o interlocutor, com o discurso do outro, etc.) O estilo entra como elemento na unidade de gênero de um enunciado. (BAKHTIN, 1997, p. 284).

Nesse sentido, em sua época, as crônicas de Invenção da cidade cumpriram a função comunicativa de narrar o cotidiano da construção de Brasília para um público que, em sua maioria, era formado por candangos. Originalmente, por serem transmitidas, pela Rádio Nacional de Brasília na hora do almoço, o estilo dessas crônicas acabam tendo uma certa peculiaridade, se comparadas com as dos cronistas dos grandes jornais desse período: Sérgio Porto, Rubem Braga, Carlos Drummond. O estilo das crônicas de Clemente Luz também foi influenciado pelas condições vividas por Clemente naquele momento, em que compartilhava de realidade semelhante a de seus ouvintes: canteiros de obras, a saudade de familiares, o ritmo de trabalho, as angústias, os medos, as incertezas e principalmente as expectativas. Ou seja, Clemente Luz tinha relação um tanto diferente com seus leitores-ouvintes. É esse aspecto que marca fortemente o seu estilo.

De acordo com Bakhtin não existe a possibilidade de separação entre estilo e gênero. Caso contrário, acarretaria toda uma série de problemas históricos. As mudanças históricas dos estilos da língua são inseparáveis das mudanças que ocorrem nos gêneros do discurso. Destarte, "a língua escrita corresponde ao conjunto dinâmico e complexo constituído pelos estilos da língua, cujo peso respectivo e a correlação, dentro do sistema da língua escrita, se encontram num estado de contínua mudança" (BAKHTIN, 1997, p. 285).

De acordo com o teórico, os enunciados e os gêneros do discurso são como correias de transmissão, visto que levam da história da sociedade à história da língua. Logo, nenhum fenômeno novo pode entrar no sistema da língua sem ter passado por um acabamento feito pelo estilo-gênero.

À vista disso, o estilo de escrita de Clemente Luz parece se modificar, à medida que Brasília vai se transformando numa cidade concreta. Clemente diversifica, dessa forma, sua linguagem de cronista diante da vivência de uma nova dinâmica social presente nos canteiros 
de obra da futura capital. De algum modo, Bakhtin (1997, p. 285) esclarece fenômenos linguísticos semelhantes a esse experimentado por Clemente Luz:

\begin{abstract}
A ampliação da língua escrita que incorpora diversas camadas da língua popular acarreta em todos os gêneros (literários, científicos, ideológicos, familiares, etc.) a aplicação de um novo procedimento na organização e na conclusão do todo verbal e uma modificação do lugar que será reservado ao ouvinte ou ao parceiro, etc., o que leva a uma maior ou menor reestruturação e renovação dos gêneros do discurso. Quando a literatura, conforme suas necessidades, recorre às camadas correspondentes (não literárias) da literatura popular, recorre obrigatoriamente aos gêneros do discurso através dos quais essas camadas se atualizaram. Trata-se, em sua maioria, de tipos pertencentes ao gênero falado-dialogado.
\end{abstract}

Nas crônicas de Invenção da cidade, observa-se uma representação do uso real da língua naquele período de formação histórica de Brasília, por meio da reprodução de diálogos orais nos locais de lazer, nos canteiros de obras, nos círculos de amizade e familiar ou até mesmo na linguagem sociopolítica do momento. Clemente Luz enriquece suas crônicas radiofônicas, por exemplo, com matéria advinda das camadas populares, justamente para uma interlocução maior com os candangos. Essa proximidade entre o cronista e seus interlocutores transforma e marca o estilo do gênero crônica praticado por Clemente Luz.

\title{
Referências
}

BAKHTIN, Mikhail M. Os gêneros do discurso. In: Estética da criação verbal. Tradução feita a partir do francês por Maria Emsantina Galvão G. Pereira. 2ํㅡㄹ, São Paulo: Martins Fontes, 1997.

SOBRAL, Adail. A estética da criação verbal. In: BRAINT, Beth (Org.) Bakhtin, dialogismo e polifonia. São Paulo: Contexto, 2009. p. 167-183.

\section{Biografia do cronista Clemente Ribeiro da Luz}


Clemente Ribeiro da Luz nasceu no dia 29 de setembro de 1920 em uma fazenda chamada Quilombo, nas proximidades da Serra da Mantiqueira, município de Delfim Moreira (MG).

Filho de Fernando da Costa luz e de Joaquina Ribeiro da Luz, nasceu numa família humilde de lavradores, tendo sete irmãos: cinco mulheres e dois homens, apenas um vivo.

Conforme diz nas orelhas de seus livros Invenção da cidade (1967) e Minivida (1972), reforçando ainda em uma entrevista oral concedida ao Arquivo Público do Distrito Federal - ArPDF em 1996, não teve uma vida fácil, e só aos trancos e barrancos, conseguiu terminar os estudos aos 22 anos de idade em Belo Horizonte. "Os meus estudos foram muito difíceis. Meu pai era muito

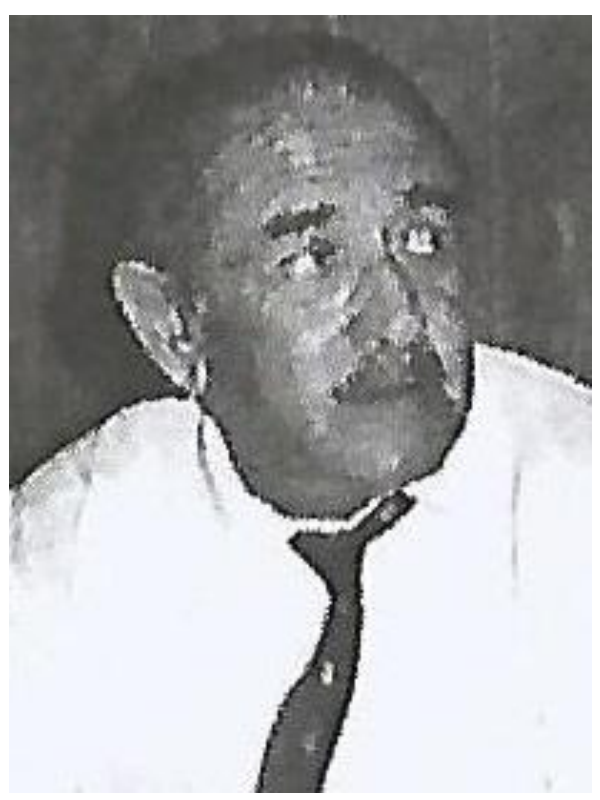

Fonte: ANE Disponível em:

http://www.anenet.com.br/clementepobre. Era administrador de fazenda, então eu não tive acesso à escola muito cedo. Consegui terminar meu ginásio aos trancos e barrancos com 22 anos”. (LUZ, 1996, p. 1).

Contava, porém, em tom de brincadeira aos amigos e também em Minivida (1972), que foi praticamente forçado a estudar pela sua mãe, sendo o único caminho que o restou em consequência de um acidente que levou três dedos da sua mão esquerda ainda menino num engenho de cana-de-açúcar, impossibilitando-o de seguir o caminho que provavelmente seria destinado a ele: o da oficina ou da lavoura. Mas, em vez de pegar no cabo da enxada, receberia educação escolar. Foi então que enveredou para o caminho da leitura e do estudo, sendo uma tarefa complicada por conta da condição financeira da sua família.

Sobre o início de sua carreira como jornalista, o próprio Clemente destaca o seguinte:

Ao mesmo tempo que eu estudava, eu fiz contato com jornais através do Marques Rebelo e através do Guilhermino César, que inclusive mora no Rio Grande do Sul, se tornou meu amigo naquele tempo. E comecei a fazer o que se fazia naquele tempo pra ser jornalista. Quer dizer, se agregar a uma Redação, trabalhar de graça o tempo que fosse necessário. E a gente só ganhava a 'permanente' de cinema, então a gente usava isso. E eu comecei a desenvolver o negócio do jornalismo, aí de repente descobri que era jornalista (...). Quando foi em 42 eu consegui me infiltrar na igrejinha literária de Belo Horizonte. Eu fazia poemas e tudo. Mostrei meus poemas, fui mostrando pra um, pra outro. De repente eu 'tava publicando um livrinho deste tamaninho. Eu nem tenho mais ele. Um livrinho com 50 poemas, até bom. (LUZ, 1996, p. 1-2). 
O livrinho mencionado por Luz é Ombros Caídos publicado em 1942, em Belo Horizonte. Na literatura, foi sua primeira obra, feita em poesia e na qual teve relativa aceitação da crítica. Mais adiante, conforme Guimarães (2005), dedicou-se à literatura infantil, escrevendo entre outras obras: Bilino e Jaca, o mágico, 1944; Infância humilde de grandes homens, 1944; Aventura da bicharada, 1949; O caçador de mosquitos, 1953; Pedro Pipoca, 1957. Um acontecimento que ficou marcado em relação a sua literatura infantil diz respeito ao elogio do cartunista Ziraldo que afirmou que "uma das leituras que mais gostara e que mais o impressionara quando criança foi O mágico, de Clemente Luz". (GUIMARÃES, 2005, p. 284).

Luz (1996) afirma que Ombros caídos (1942) revelou uma marca de sua personalidade àquela época, marcada pela baixa autoestima. Assim, em 1942, mesmo com um emprego estável no Diário da Tarde em Belo Horizonte, resolveu ir para o Rio de janeiro, onde trabalhou em O Jornal, ficando lá até 1946. Depois, já casado com Edith Viana Faria com 22 anos e com dois filhos, voltou para o Diário da Tarde. Ficou nesse jornal até 1953.

Quando Juscelino Kubistchek se candidatou à Presidência da República, foi convidado para trabalhar no comitê dele como jornalista no Rio de Janeiro. Antes disso, já havia trabalhado para Juscelino na prefeitura de Belo Horizonte. Além de se dedicar ao comitê eleitoral, atuou também em outros jornais do Rio. Durante esse momento, trabalhou no Serviço Social da Indústria - Sesi, na assessoria de Comunicação Social. Já em 1956, após as eleições, passou trabalhar no jornal $A$ Noite, como secretário de redação até o fechamento da empresa.

Com o início da construção da nova capital, conseguiu um emprego como redator da Rádio Nacional de Brasília, já instalada na cidade em construção, com a ajuda de Mário Pires, então superintendente da rádio, de outro amigo em 1958. Chegou inicialmente sozinho e, depois de um tempo, trouxe sua família. Luz foi o primeiro jornalista profissional instalado em Brasília, conforme depoimento:

Agora, nessa minha instalação na rádio, eu cheguei aqui, o trabalho de jornalismo, pra onde eu vinha, não era feito porque ninguém sabia bem como fazer, a não ser o Américo Fernandes, que era um jornalista, que já estava aí instalado, jornalista goiano. Ele foi o primeiro jornalista que se instalou aqui. Agora, profissionalmente, o primeiro jornalista que se instalou em Brasília fui eu. Que eu além de trabalhar pra Rádio Nacional, eu tinha uma correspondência com a Agência Meridional dos Diários Associados e com a Agência Nacional do governo. Então uma vez por semana pelo menos, eu tentava o rádio da Novacap, aqui onde é hoje a Velhacap... nos postos ali (...). Então ali, uma vez por semana eu ia lá transmitir notícias pra Agência Meridional 
e pra Agência Nacional. Ou então mandava por avião, todo dia a gente ia no aeroporto. (LUZ, 1996, p. 7-8).

Foi neste período que, por acaso, Clemente Luz começou a desempenhar o papel de cronistas: “(...) Leoni Mesquita, que era o diretor saiu feito doido catando gente que pudesse fazer a coisa. Por avaliação e por eliminação, chegaram à conclusão que o único camarada que podia fazer essa crônica e que era alfabetizado era eu" (LUZ, 1996, p. 8). O cronista conta um episódio curioso a respeito da sua primeira crônica:

Então me chamaram pra escrever a crônica. O pior é que eu bebia demais, bebia mesmo, eu bebia com vontade. Então combinaram que a crônica seria inaugurada amanhã às 9 horas. Eu: "Tá certo, amanhã às 9 horas eu tô indo pra rádio." Aí fui pra casa, bebi meu porre, tomei meu porre, tomei meu café de porre, quando foi 7 horas da manhã todo mundo atrás de mim: "Cadê a crônica, cadê a crônica?" Eu falei: "Eu não levantei ainda. Espera aí." Eu tinha consciência em mim. Eu sabia que eu era capaz de fazer a coisa, 'tava pouco ligando. Quando foi mais ou menos 8 horas, 8 e meia, eu sentei na máquina e pa-rá, pa-rá, pa-rá, pa-rá, pa-rá, pa-rá. Eu tinha a máquina em casa, "tá aqui". E por sorte eu fiz uma crônica muito bonita, muito gostosa. Foi um estouro, então foi o primeiro estourinho assim, de crônica. $E$ a crônica foi a maior e a melhor, a maior e a melhor de Brasília. Porque o seguinte: não tinha outro, era só eu, era só eu. Não tinha outro não, era só eu mesmo. Então eu estou acostumado a brincar assim: "Sou o maior e melhor cronista de Brasília." (LUZ, 1996, p. 8).

Dessa forma, todos os dias na hora do almoço, uma crônica era lida, "com audiência compulsória e obrigatória nos acampamentos e nos refeitórios", como diz Clemente. Muito devido a alto-falantes instalados nos refeitórios ou mesmo aqueles que sincronizavam os radinhos de pilha para escutá-las. As crônicas eram muito bem lidas por Sérgio Dias e Rui Carneiro.

De acordo com o cronista, se pegarmos o livro Invenção da Cidade, descobriremos "coisas corriqueiras que... coisas que você não imagina que possa dar uma crônica. Com qualquer coisa eu fazia uma crônica. Então eu cheguei à conclusão que uma frase qualquer dá pra você fazer uma crônica de rádio". (LUZ, 1996, p. 8). Luz também produziu crônicas diárias para jornal, mas teve muita dificuldade, justamente pelo fato de que as da rádio eram mais livres, cheias de brincadeiras. As mais "sérias" foram feitas para o jornal de Brasília. Luz revela que nesse período muitas pessoas o procuravam para contar suas histórias, já que com o tempo, o mesmo se tornou mais conhecido nos canteiros de obras e principalmente bares, como bom boêmio que era.

Vale ressaltar que antes de escrever as suas primeiras crônicas para a Rádio Nacional de Brasília, Clemente Luz já havia trabalhado na Rádio Guarani em Belo Horizonte, onde 
ajudou na área de produção do primeiro jornal falado da cidade. Nessa época não chegou a fazer crônicas, mas chegou a ensaiar umas "cronicazinhas" algumas vezes, nunca levadas a sério: “ (...) crônica mesmo, eu vim produzir aqui em Brasília, depois que eu vim pra cá, e que é uma história muito engraçada. Quando eu vim pra cá em agosto de 58 , eu cheguei aqui, a Rádio Nacional tinha sido inaugurada em maio, então eu vim logo em seguida, como redator da rádio". (LUZ, 1996, p. 4).

Logo, instalou-se essa rotina do almoço dos pioneiros da construção de outubro de 1958 até depois da inauguração da nova capital. Após a inauguração da cidade, as crônicas foram suspensas, pois o cronista não simpatizava com o novo presidente Jânio Quadros. Em 1961 Luz saiu da rádio, voltando apenas em 1963.

É notório que uma das profissões exercidas por Clemente Luz em Brasília foi a de vendedor de jornais. "Então eu quis ficar rico vendendo jornal. Quando eu vim pra cá, eu descobri que eu poderia ficar rico vendendo jornais. Porque aqui não tinha jornais. Então eu organizei um sistema de vender jornais a partir do aeroporto. E tinha uma banca na Cidade Livre onde eu tinha um alto-falante lá." (LUZ, 1996, p. 10). Luz até tinha uma equipe de vendedores, vários fornecedores (O Globo, O Estado de S. Paulo, a Folha de S. Paulo, entre outros), chegando a vender milhares de exemplares para diversos acampamentos na construção. Contudo, a empreitada de ficar rico nesse ramo acabou não se concretizando por diversos motivos, especialmente por suas gastanças exageradas.

Outra profissão exercida em Brasília foi a de escriba, para ajudar candangos que buscavam uma maior comunicação com familiares por meio de cartas, já que os meio de comunicação eram precários e bem limitados naquele período. Clemente e seus filhos escreviam cartas no final da década de 1950, bem como liam as que chegavam, ganhando um bom dinheiro nesse período. De acordo com Luz (1996, p. 12):

Os caras me pediam pra escrever carta. Aí instituí o dia das cartas. Escrevíamos o que eles queriam. No sábado e o domingo a gente punha a cadeira e um banquinho lá assim e eu e meus filhos escrevíamos as cartas pros candangos. Escrevíamos o que eles queriam. Tinha sábado que a gente escrevia 30, 40 cartas. E ganhava um dinheirinho, a gente cobrava, nem sei quanto a gente cobrava. Mas sempre dava pra beber cerveja. 
Isso se deu pelo fato de que a maioria dos candangos não possuía muito estudo, vivendo angustiados para receber e transmitir informações a familiares que estavam a quilômetros de distância. Aliás, em muitas crônicas, Luz deixa transparecer conteúdos dessas cartas.

Suas crônicas foram organizadas em dois livros que só foram publicados nas décadas de 1960 e 1970. O primeiro em 1967 intitulado Invenção da cidade, obra com apresentação manuscrita de Juscelino Kubitscheck e prefácio de Israel Pinheiro; e o segundo, Minivida, de 1972 que complementou o primeiro. Mas conforme depoimento dado ao ArPDF, Luz escreveu milhares de crônicas. Segundo ele, se essas fossem organizadas e publicadas, resultariam em toneladas de livros. Por isso, escolheu as suas melhores.

No prêmio Os melhores da Rádio Nacional de Brasília de 1959, escolhidos por uma comissão, Clemente Luz foi reconhecido pelo seu trabalho como cronista (Correio da Manhã p. 5, 5 Jan. 1960). Além disso, em 1967 ficou em quinto lugar no II Concurso Nacional de Jornalismo, organizado pela Prefeitura do Distrito Federal - PDF, para reportagens acerca de Brasília do Diário de Minas (Correio da Manhã p. 5, 8 Mar. 1967).

Luz foi premiado no concurso literário da Fundação Cultural do Distrito Federal. Participou da Antologia dos poetas de Brasília, organizada por Joanyr de Oliveira (1971) e de Cronistas de Brasília, obra organizada por Aglaia Souza (1995). Além disso, Clemente colaborou na fundação da Associação Nacional de Escritores - ANE.

Foi sem sobra de dúvidas, o primeiro cronista de Brasília e símbolo do pioneirismo da literatura brasiliense. Destarte, "como pioneiro, exerceu as diversas de jornalismo, tendo sido poeta e cronista. Trabalhou no Diário Oficial do Distrito Federal e foi premiado em concurso literário da Fundação Cultural do DF" (GUIMARÃES, 2005, p. 284) Clemente Luz, é muito respeitado por grandes expoentes da literatura brasiliense como Almeida Ficher e Conceição Freitas. Desta forma, Almeida Ficher em A literatura de Brasília (1983), diz que as crônicas de Clemente Luz falam das dificuldades dos primeiros tempos da edificação da Nova Capital, das alegrias e tristezas de sua população mais permanente e menos privilegiada. Já Conceição Freitas (2003), relata suas impressões sobre o cronista no artigo-entrevista no Correio Braziliense, assim sendo, a mesma revela que sentiu inveja de Clemente Luz, por não ter presenciado tudo que o cronista viveu no período da construção de Brasília. A autora, por conta disso, o batiza de Pero Vaz de caminha. 
Clemente Luz possui a marca do pioneirismo, delicadeza, modéstia, e principalmente, a atenção ao contexto da construção da nova capital, demonstrando em suas escritas uma suavidade brilhante. Faleceu em 17 de outubro de 1999 em Ceilândia-DF.

\section{Referências}

FREITAS, Conceição. Pero Vaz de Brasília, Correio Braziliense, 26 ago 2003.

COSTA, Luiz Carlos Guimarães da. História da literatura brasiliense. Brasília: Thesaurus, 2005.

LUZ, Clemente Ribeiro da. A invenção da cidade. Apresentação de Juscelino Kubitschek; prefácio de Israel Pinheiro. DF: Editora Horizonte - EBRASA, 1967.

Federal, 1996. . Depoimento - Programa de História Oral. Brasília, Arquivo Público do Distrito . Minivida. DF: EDIPLAN, 1972.

(SEM AUTORIA): Melhores de Brasília. Correio da Manhã, Rio de janeiro, p. 5, 5 Jan. 1960. Disponível

em:

http://memoria.bn.br/DocReader/Hotpage/HotpageBN.aspx?bib=089842 07\&pagfis=141\&u rl=http://memoria.bn.br/docreader Acesso em: 06 de Abril de 2017.

(SEM AUTORIA): Prefeitura dá prêmio a jornalistas. Correio da Manhã, Rio de janeiro, p. 5, 8 Mar.1967.

Disponível

em:

http://memoria.bn.br/DocReader/Hotpage/HotpageBN.aspx?bib=089842 07\&pagfis=141\&u rl=http://memoria.bn.br/docreader Acesso em: 06 de Abril de 2017.

\section{Resenha do livro Invenção da Cidade de Clemente Luz (1967)}

Clemente Ribeiro Luz nasceu numa fazenda chamada Quilombo em Delfim Moreira (MG), no dia 29 de setembro de 1920. Era jornalista. Exerceu o cargo de secretário de redação em vários jornais de Minas Gerais, Rio de Janeiro e Brasília; como o próprio autor revela na orelha do seu outro livro Minivida (1972). Chegou à nova capital em 1958, onde trabalhou como cronista diário da Rádio Nacional de Brasília, no período da construção da Capital escrevendo várias crônicas que retratavam a luta diária dos candangos na edificação de Brasília. Destarte, seus manuscritos foram organizados em dois livros que só foram publicados 
depois. O primeiro em 1967 intitulado Invenção da cidade, obra esta com apresentação manuscrita de Juscelino Kubitscheck e prefácio de Israel Pinheiro; e o segundo, Minivida, de 1972 complementando o primeiro. Clemente Luz faleceu em 17 de outubro de 1999 em Ceilândia-DF.

Fez-se necessária essa breve apresentação do autor por conta do seu anonimato em relação a Brasília, mesmo sendo apontado por Luiz Carlos Guimarães da Costa como o primeiro cronista de Brasília e símbolo do pioneirismo da literatura brasiliense. Assim sendo, Clemente Luz "como pioneiro, exerceu as diversas de jornalismo, tendo sido poeta e cronista. Trabalhou no Diário Oficial do Distrito Federal e foi premiado em concurso literário da Fundação Cultural do DF" (GUIMARÃES, 2005, p. 284).

Luz também colaborou em periódicos e pertenceu à Associação Nacional de Escritores e foi premiado no concurso literário da Fundação Cultural do Distrito Federal. Muito respeitado por grandes expoentes da literatura brasiliense como Almeida Ficher e Conceição Freitas, possui a marca do pioneirismo, delicadeza, modéstia, e principalmente, a atenção ao contexto da construção da nova capital, demonstrando em suas escritas uma suavidade brilhante.

O Livro Invenção da cidade é composto por 83 crônicas bem distribuídas. Salvante o texto inicial que se assemelha a um prefácio. A obra é dividida em quatro partes nomeadas como "livros", sendo que estes possuem subdivisões que reúne um conjunto de narrativas sob determinado vínculo temático. Na primeira crônica, um nome a margem, Luz comenta sobre sua política literária, justificando a ausência de um personagem, Juscelino Kubitschek. Para ele o trabalho diário de escrever sobre a cidade, que se erguia no Planalto Central, sendo mais inventada do que construída, face à exiguidade do tempo e à grandiosidade dos projetos, nunca havia lhe ocorrido a necessidade de exaltar a figura de JK, presente em carne e espírito em cada canteiro de obras, em toda a extensão do sítio demarcado para implantação do novo Distrito Federal. Assim, para Luz (1967, p. 18) “Brasília e JK eram dois nomes entrelaçados de tal maneira, como nomes de namorados traçados num tronco - só se separariam pela ação da fatalidade, com o corte criminoso do tronco ou a sua derrubada pelo raio imprevisível e irreversível", além disso, o autor também apresenta outra razão para a ausência-presença de JK.

(...) [Clemente Luz] no seu falar diário com o povo, que edificava a cidade, não havia precisão de lembrar o nome de Juscelino. Ele estava em tudo sobre o que se falasse ou se escrevesse, como a poeira da terra revolvida, porque 
era a própria essência do entusiasmo que a todos contaminava, da Cidade Livre aos acampamentos de obras, que se estendiam, como pequenas ilhas de luz, no mar verde-amarelo do sítio onde hoje se ergue o Plano Piloto. (LUZ, 1967, p. 18)

Feitas as devidas justificações, o autor inicia seu "primeiro livro" - Tempo do Louva-aDeus. Em Encontro Matinal, a crônica que inaugura o livro, Clemente Luz se utiliza da figura do Pequeno Príncipe para explicar a construção de Brasília, uma vez que o personagem possui uma curiosidade característica da inocente das crianças. Assim, por meio de algumas indagações do personagem o autor vai explicando o porquê de tantos homens trabalhando, dos monumentos bonitos que estavam sendo construídos e principalmente da importância da mudança da capital para o planalto central. Aliás, Clemente Luz é notável, quando se utiliza do olhar das crianças para explicar suas crônicas, demonstrando jeitos, costumes, medos, angústias e principalmente o cotidiano infantil, como acontece nesta e em algumas outras crônicas do livro.

Em Elementos, um subgrupo do "primeiro livro", o autor apresenta ao leitor estórias características dos primeiros tempos da construção, como o ritmo da construção e o entusiasmo, alguns personagens, mitos e uma cidade que passou a ser chamada de livre. Em Cidade Livre, Luz (1967, p. 39) menciona que "assim como os acampamentos, a Cidade livre foi matéria prima indispensável para que se escrevesse o poema épico que é Brasília". Para ele, um dia, teria que ser escrita a história dessa cidade, que era mais coração do que matéria aberta ao sol, cidade "onde as oportunidades se ofereciam a todos ou se negavam a todos na mesma proporção. (...) Cidade esta que nasceu condenada ao desaparecimento, como o homem nasce condenado a morte, depois do tempo de vida necessário" (Luz, 1967, p. 40).

Em Louva-a-Deus, outro subgrupo, o cronista trabalha a questão do espaço, da arquitetura e urbanismo, além das particularidades de uma cidade em construção. Como em o Croqui, onde o literato menciona que nunca chegou a ver o desenho da futura capital como um avião e sim, de um enorme louva-a-Deus pousado, estando "pronto para levantar voo e destruir, com um movimento inesperado de suas asas, o sonho maravilhoso de Brasília. (Luz, 1967, p. 50).

Em Alvorada de espelhos, fica evidente o quanto o real se mistura com o imaginário no processo de construção de uma cidade planejada como alerta Laurent Vidal (2009). Fazendo uma analogia ao desenvolvimento de uma menina-mulher, Luz diz que no final de 1950 a cidade era inventada, porque não havia tempo para ser elaborada e planejada. Que 1959 a 
cidade é inventada, mas, que também se reinventa, "a cada instante ante os olhos atônicos de homens e crianças. É a jovem futura cidade que, como uma jovem futura mulher, está desabrochando para a vida" (Luz, 1967, p. 52). Em outras palavras, a cidade era construída e inventada. Contudo, a cada amanhecer era reinventada pelo entusiasmo, pela alegria da promessa, misturado ao amargo do mistério e da incerteza da entrega no prazo.

No subgrupo Candangos do "primeiro livro" Luz trata do cotidiano, dos costumes e maritalmente de aspectos simples, porém, extremamente significativos para se entender o que é realmente o ser chamado candango. O cronista apresenta a importância do Canto Noturno para os trabalhadores nas obras, como num mutirão de roça, onde entoavam canções regionais; "cantos simples e profundo, talvez sem alegria, mas honesto e bravo. [Pois] a noite traz o sono. [E] a luz elétrica entorpece um pouco a vista e os músculos". (Luz, 1967, p. 52). Ou seja, os trabalhadores noturnos cantavam para não dormir e para que consequentemente, o ritmo da construção não diminuísse.

Em A Mala de Madeira é revelada a importância da mesma na vida de um candango. Talvez a mais importante, pois é a fiel companheira do imigrante na procura de uma vida melhor: longe da seca, da miséria e da pobreza. Desta forma:

A mala de madeira é a sua casa, é o seu mundo. Quando partiu, juntou o que tinha: roupas, alpercatas, algum dinheiro, embolou tudo com esperanças de conquistar o sul do país, e desceu. A mala lhe serviu de banco, na hora do descanso ou da comida escassa e dosada; a mala lhe serviu de travesseiro, quando teve de recostar o corpo à sombra de uma árvore ou à beira de um rio para recuperar um pouco das forças desgastadas... (Luz, 1967, p. 71).

Ainda nesse subgrupo nos deparamos com a importância e o significado de um caneco de alumínio ou mesmo de ferro esmaltado para os mesmos imigrantes. Em O caneco, o leitor percebe que no período nada era mais sagrado e importante, sobretudo, para o trabalhador nordestino. Nem a escova de dente, de uso tão pessoal e íntimo era mais importante do que o caneco pendurado no cinto. Onde quer que fosse ele o carregava, o que acabou o tornando reflexo desse trabalhador: as agruras de uma penosa viagem, a fuga para o sul, a miserabilidade daqueles que já sofreram muito.

Em Cartas, notamos que a profissão de escriba é resgatada do período em que os grandes reis ainda não manipulavam a pena. Em Brasília, a profissão tinha grande popularidade. Além disso, essa crônica demonstra a angústia misturada à saudade daqueles que deixaram entes queridos para viver o sonho da construção da nova cidade: mães, noivas, 
esposas, filhos, entre outros. Essas cartas eram carregadas de aflição, raiva, saudade, amor e tristeza, daqueles que estavam a quilômetros de distância das pessoas que amavam.

Cumeeiras, último subgrupo do "primeiro livro" representa a fase final da construção. É notório que o termo "cumeeira" diz respeito a fase final da construção de uma casa, onde antes da mudança para a nova residência é feita uma festa para comemorar a finalização do trabalho árduo, esta, a Festa da cumeeira.

Aspectos cotidianos do final da construção são citados nesse subgrupo: a cidade na fase final da construção, os animais, os trabalhadores e a ansiedade pela inauguração. A crônica Ilhas de Luz, revela que a cidade a noite parecia com um arquipélago formado por um conjunto de ilhas de luz, demonstrando a grandeza da construção de Brasília. Assim,

Esta visão noturna dá bem a ideia dos espaços vazios e dos pontos de concentração de trabalho, onde se forja a cidade, que não está nascendo do centro para a periferia. Ela está edificando em quase toda a sua extensão, simultaneamente, por obra e graça do espírito de equipe, que preside no trabalho de execução do plano gigantesco. (Luz, 1967, p. 97).

Segundo Luz (1967, p. 98), os canteiros de obras e os acampamentos se apresentavam como estas pequenas e grandes ilhas de luz, "brilhando no oceano ondulado do Planalto. No oceano manso e ondulado do Planalto, onde navegam, sem temores, as esperanças de todo um povo". Já em Figurinha Difícil, em meio a febre dos álbuns de figurinhas no período, de norte a sul do Brasil. Em Brasília não era diferente. Mas na futura capital seria lançada - na imaginação do cronista - um álbum de figurinhas sobre a cidade. Esse álbum diminuiria a "distância” em entre os grandes expoentes de Brasília/NOVACAP com a população. Isto é,

Imaginemos que alguém de ideias luminosas resolva fazer uma divulgação diferente de Brasília. Imaginemos que organize um álbum de figurinhas, desses que andam por aí nas mãos da gente miúda e da gente grande também. $O$ álbum seria preenchido com fotos impressas em cores, fixando homens e cenas de Brasília. No álbum figurariam os maiorais, a começar pelo Juscelino, passando por Eleonôra para terminar no candango simples e tranquilo. (Luz, 1967, p. 125).

O interessante desta crônica fica por conta da imaginação da imaginação, ou seja, a história é narrada em um bar da cidade livre de forma hipotética pelo primeiro cronista da cidade. Além disso, fica evidente a crítica do literato à idealização dos ditos "maiorais" da futura capital, e principalmente, a distância existente os ditos maiorais e os candangos simples e tranquilos. Assim, o álbum proporcionaria uma intimidade maior dessa classe para com 
esses grandes expoentes, sendo nomeados apenas pelo primeiro nome ou até mesmo por apelidos que caracterizam a intimidade mediante as trocas e/ou vendas de figurinhas.

No "segundo livro" Itinerário da Solidão não há subgrupos. Este livro é um misto de crônicas relacionadas à arquitetura da nova capital, a solidão daqueles que participam desse grande processo. Flor Agreste trata de uma flor no cerrado e sobretudo, dos impactos de uma flor solitária, Brasília, na região do planalto central; lembrado daqueles que já viviam na região com suas memórias que na maioria das vezes foram esquecidas. Assim, "Brasília, como tu, abriu-se no planalto, como grande flor de terra e ferro, antecipando-se à primavera e ao renascimento" (LUZ, 1967, p. 138). Em Mensagem dos Ausentes, voltamos no tempo para sentirmos a solidão daqueles que foram trabalhar em Brasília. Os ausentes levavam o calor de seu carinho, por meio de cartas ou mensagens, transportados por corações amigos. Contudo, a ótica da crônica é voltada para o transporte e todo o processo pelo qual essas mensagens dos ausentes passavam para chegar até os corações angustiados pela falta de informação. $O$ cronista menciona os noivos de Brasília, a alegria e/ou tristeza proporcionada pela leitura de uma carta, um bilhete. Para Luz, que também compartilhava desses sentimentos,

Todos nós, que aqui estamos, na imensidão do planalto, sentimos, na solidão dos alojamentos, a necessidade dos retalhos de vida, que as cartas nos trazem. Elas são, como o alimento diário, necessárias e indispensáveis, para que os corpos e mãos possam trabalhar em sossego, no sadio entusiasmo de construção da cidade... (LUZ, 1967, p. 150).

A Carta, vai nessa mesma perspectiva. Um jovem noivo de Brasília esperava ansioso pelo contato da sua amada havia um om tempo. Até que um dia ela veio e, com ela, a emoção e as lágrimas. Onde, "o jovem senhor do mundo, vaidoso por possuir o coração de uma mulher, começou a dar risadas e a sentir-se cada vez maior, até o instante em que a saudade, que dormia no fundo do coração, se derramou em lágrimas sobre a mesa do bar!..." (LUZ, 1967, p. 154).

Em Fantasma no Alvorada, Luz deixa escapar toda a sua paixão pela arquitetura de Brasília, especialmente o Palácio da Alvorada, como ele mesmo diz: o Palácio de Juscelino, pois mesmo deixando a presidência, ele e sua família serão os donos do palácio, os fantasmas amigos da Alvorada, pois suas presenças estarão em tudo e em cada canto do palácio por terem sido os primeiros moradores. 
No "terceiro livro", o Tempo do Encontro, o autor aborda a fase final da construção da cidade, mencionando diversos encontros da cidade tais como: o das aguas, atribuídos ao Lago Paranoá; dos quadrantes à cidade e toda o início da "ocupação da cidade", que ainda estava sem vida e com muitos apartamentos vazios; e a dos caminhos, referente as peculiaridades da mudança da capital, a ansiedade pela pelo 21 de abril e principalmente os rumos que a cidade - que ligava agora todos os caminhos do país como pretendia JK - iria tomar. Em Encontros das aguas, subgrupo, o autor se mostra entusiasmo com o lago, no entanto, crítico quando aos moradores, Os afogados da Vila Amaury, também chamada de Bananal; vila essa que foi coberta pelas aguas do Lago.

Em A casa flutuante, Clemente Luz sonha em obter de Juscelino um pedaço do lago, para viver ali como numa "arca de Noé". Leria vários livros e flutuaria tranquilo, sem as preocupações de uma vida agitada, parando apenas para reabastecer e trocar o livro. Ou seja,

Levantaria a âncora e içaria a vela colorida. O vento matinal levaria minha casa, através do lago, até um pequeno porto. Reabasteceria o meu pequeno mundo.... Compraria novos livros, talvez recebesse alguns conhecidos. E se a fiscalização viesse, para me dizer que eu estava fora do meu lote, ligaria o motor de popa e rapidamente voltaria, com o auxílio de uma bússola, ao ponto demarcado. Se quisessem desalojar-me, eu diria: - estou na minha casa, construída sobre o meu lote, que o presidente me deu! (...) E se não acreditassem, eu pediria que esvaziassem o lago, para ver se minha casa não baixaria, como a Arca de Noé, sobre o ponto demarcado. (LUZ, 1967, p. 198199).

Essa crônica explicita bem o teor crítico das narrativas de Clemente Luz, transparecendo o tempo todo ao leitor que ele está lá, fazendo parte daquele lugar e período, vivenciando como os demais brasileiros aquele momento histórico do Brasil.

Em A posse, do subgrupo encontro dos quadrantes, nos deparamos com a ansiedade da inauguração, da enfim, integração nacional. Onde Juscelino está à espera das colunas de Integração Nacional que chegariam ao Planalto para tomar posse da terra conquistada. Onde todos aguardavam debaixo do céu úmido da manhã de janeiro. Para Luz (1967, p. 219). “As caravanas chegaram, os homens deixaram os carros e caminharam para o lugar preparado para a missa. E quando JK deixou o interior do pequeno veículo não teve tempo sequer de abrir os braços (...)".

No subgrupo Encontro dos Caminhos temos a mudança, e com ela, a esperança, o entusiasmo. As surpresas que a cidade revelou aqueles que vieram com um pé atrás. $\mathrm{Na}$ crônica Cortina de barba, Luz faz uma crítica sutil ao reconhecimento daqueles que edificaram 
a cidade. Desta forma, surgiu no bar uma ideia maluca para poder diferenciar no dia 21 de abril aqueles que participaram da edificação de Brasília dos que chegaram para dela tomar posse: deixar a barba crescer. Para ele,

Os que pretendiam erguer a cortina de barba, boêmios alegres e divertidos, eram homens satisfeitos e triunfantes, que concluíam, naqueles dias, uma nobre tarefa. Queriam apenas a criação de um sinal que os diferenciasse, no momento em que deveriam entregar, aos que chegariam daí a pouco, aos pioneiros da mudança efetiva, o apartamento, o escritório, a sala de trabalho. (LUZ, 1967, p. 229).

Mediante uma sequência linear dos acontecimentos, o "quarto livro", Navio ancorado, trata do período pós-inauguração. Sendo relevantes temas sobre a ocupação da cidade, a formação de uma identidade, a questão da moradia e os preços para se conseguir um lote na nova capital.

Em O Brasiliense o cronista diz que já não era novidade e que não dava mais para contar nos dedos as crianças nascidas em Brasília. Assim, num episódio onde os pais discutindo a volta para a antiga capital, Rio de Janeiro, simplesmente se esqueceram de pedir a opinião dos seus dois filhos. Tal ação acabou ocasionando uma verdadeira surpresa, uma vez que, o filho mais velho não queria ir para o Rio já que era de Brasília, assim como o irmão mais novo. A crônica, demonstra que Brasília já começava a gestar a sua população, esta, na sua grande maioria, nascida na nova capital.

O livro Invenção da Cidade é significativo pelo fato de que Clemente Luz está preocupado em registrar o lado humano de um projeto ambicioso, parte importante de um projeto desenvolvimentista de JK do final da década de 1960. O primeiro cronista de Brasília é diferente, sobretudo, porque apresenta não apenas nesta obra como também em Minivida as estórias simples e humanas da cidade que era mais inventada do que construída e mais à frente reinventada a cada dia.

Como o próprio cronista menciona no prefácio de Minivida, estes dois livros "falam da gente e das coisas de Brasília sem pretensões maiores. [Reunindo estórias de] vida miúda, de esperanças, de desencontros, de humor às vezes amargo, não raro simplória; mas tenazmente gente, vencendo os dias, para compor com sua simplicidade, a argamassa humana da cidade que se estrutura e se consolida" (LUZ, 1972, p. 6).

Em Invenção da cidade encontramos uma visão ampla da construção, da inauguração e dos primeiros tempos da nova capital, Brasília, como confirma JK no prefácio do livro. Luz 
apresenta a súbita invasão do cerrado, o trabalho árduo e o pioneirismo do candango, que trabalhava até 18 horas por dia com o ritmo dos tratores e do barulho dos martelos. Que a noite, com som das cantorias regionais, os operários cantavam para que o cansaço não dominasse seus corpos e abaixassem suas pálpebras, atrasando a obra.

Clemente luz permite ao leitor viajar no tempo para vivenciar o imaginário da época: o entusiasmo, a dedicação, os costumes, os tédios e as diversões, sendo ele, também um pioneiro. Retrata, em páginas simples, com uma escrita suave e humana a saudade da mãe, da noiva, dos filhos; a saudade de pessoas que escolheram se exilar para o bem maior de uma nação inteira que lhe negaram (ou pelo menos tentaram) um pedaço de chão na cidade que os mesmos edificaram.

É tocante o fato de que as crônicas foram escritas durante o dia-a-dia da construção, no decorrer dos trabalhos nos canteiros de obras da cidade; sendo estas transmitidas, na hora do almoço, pela Rádio Nacional de Brasília. Sendo que o autor não as modificou, preservandoIhe a autenticidade e a espontaneidade. Daí a importância dessa obra, uma vez que o leitor tem o prazer de participar junto destes pioneiros da construção, ou melhor, da Invenção da Cidade por meio da literatura.

\section{REFERÊNCIAS}

COSTA, Luiz Carlos Guimarães da. História da literatura brasiliense. Brasília: Thesaurus, 2005.

LUZ, Clemente. A invenção da cidade. Apresentação de Juscelino Kubitschek; prefácio de Israel Pinheiro. DF: Editora Horizonte - EBRASA, 1967.

Minivida. DF: EDIPLAN, 1972.

VIDAL, Laurent. De Nova Lisboa a Brasília: A invenção de uma capital (séculos XIX-XX). Brasília: UnB, 2009.

\section{O panorama da crônica brasileira na década de 1950 e 1960}

É notável que a crônica brasileira adquiriu um sentido mais diversificado a partir do século $X X$, muito em consequência do desenvolvimento do jornalismo. Nesse caso, muitos jornais passaram a publicar uma seção - as vezes diárias - na qual crônicas eram publicadas. 
De acordo com William Valentine Redmond (2010, p. 138), "em caráter de relato histórico, que é o significado tradicional pela sua etimologia e com uma nova roupagem, passou a ser usada com o sentido específico generalizado em literatura estritamente ligada ao jornalismo".

Dessa forma, os relatos e comentários de fatos do cotidiano presentes em seção de jornais (Correio da Manhã, Última Hora, Jornal do Brasil), tornaram o vocábulo "crônica" parte integrante do jornal, contribuindo para esse gênero do discurso novas características para a época. Ilustrava as incertezas, as angústias, a luta e as inquietações do ser humano no seu diaa-dia. Logo, para Redmond (2010, p. 138), "sob a atmosfera do Romantismo, o jornal cresceu no Brasil, o que contribuiu para o acento lírico predominar sobre a crônica, passando esta, a ser concebida como sinônimo de gênero literário, mantendo inter-relações com a prosa ou a poesia".

Assim sendo, a crônica, com breves comentários sobre algum fato do cotidiano, passa ser mais veiculado na imprensa, com finalidade utilitária e, com o objetivo de agradar aos leitores dentro de um espaço de mesma localização: o jornal. Assim, poética ou irônica, seu motivo são os pequenos acontecimentos: a notícia em que ninguém prestou atenção, cenas do cotidiano, tudo o que é corriqueiro, sendo isso possível por uma familiaridade entre o escritor e aqueles que o leem. (REDMOND, 2010).

Isso vai de acordo com o que foi proposto por Ricardo André Ferreira Martins (2013), já que a crônica foi o gênero do discurso escolhido pelos escritores brasileiros do século XX, sobretudo, porque era o principal meio de comunicação entre os literatos e o grande público leitor, formado especialmente por leitores de jornais, que buscavam nessa seção um momento de relaxamento entre as notícias sérias e ásperas do dia-a-dia. Assim sendo, nessa configuração estreita entre jornalismo e literatura, diluindo e muitas vezes dissolvendo os limites entre os campos profissionais e sociais, muitos escritores emergiram, já que estavam mais próximos e possuíam uma comunicação maior com seus leitores, consequência de uma escola jornalística que estreitava a relação com a literatura.

Ao lado disso, a "escola" jornalística formada por escritores foi crucial para criar e mesmo influenciar o surgimento e o desenvolvimento de praticamente todos os gêneros jornalísticos, ao passo que muitos gêneros jornalísticos influenciaram a feição de vários gêneros literários importantes, como o romance, o conto e, por fim, a crônica, que no Brasil sempre foi o espaço privilegiado de registro de impressões do cotidiano, da cultura, da política, da sociedade, sempre temperada pelo apurado 
trabalho de escritores que ajudaram a alçá-la à nobre condição de gênero literário. (MARTINS, 2013, p. 2).

É nesse cenário que Clemente Luz (e provavelmente por conta dessa relação) começa a produzir suas crônicas, no final da década de 1950. Durante os anos de 1950 e 1960 grandes cronistas brasileiros como Carlos Drummond de Andrade, Sérgio Porto, (ou o célebre Stanislaw Ponte Preta), Manuel Bandeira, Rubem Braga, Fernando Sabino, Rachel de Queiroz, Paulo Mendes Campos, Clarice Lispector, entre muitos outros, contribuíram bastante para o estilo característico de observar o cotidiano e registrá-lo, com um tom muitas vezes sarcástico, simples, atravessado de ironias e com bom humor. Para Joaquim Ferreira dos santos (2007), em As cem melhores crônicas brasileiras:

\begin{abstract}
A impressionante coleção de grifes literárias escrevendo nos jornais e revistas dos anos 1950 e 1960 ajudou a consolidar a crônica como o gênero literário mais próximo do brasileiro. Muitos leitores se aventuraram a voos mais profundos a partir do gosto que tomaram pelas páginas de Fernando Sabino e Paulo Mendes Campos na revista Manchete. No jornal Última Hora, revezavam-se os estilos de Antônio Maria, romântico, e Stanislaw Ponte Preta, humor escrachado. No Correio da Manhã, no final dos anos de 1950, estava Drummond; no Jornal do Brasil, no final dos 60, Clarisse Lispector. Era uma turma de respeito ensinando o brasileiro a ler e, pela falsa simplicidade da coisa, a tentar escrever (...). (SANTOS, 2007, p. 20).
\end{abstract}

Posto isso, provavelmente muitos desses cronistas, podem ter contribuído para a construção do estilo de escrita do cronista Clemente Luz. Talvez o fato de Clemente ter trabalhado em Brasília com venda de jornais de diferentes regiões do Brasil seja relevante para seu contato com textos de outros cronistas da época. Contudo, é necessário também levar em consideração alguns pontos que diferenciam Clemente Luz dos demais cronistas acima mencionados, tais como: a forma de comunicação com o leitor (no caso seu caso, feito a priori mediante uma rádio); o público leitor, no caso de Clemente Luz, ouvintes, um público bem definido (pioneiros da construção de Brasília), diferente dos outros cronistas da época, que não tinham essa definição tão clara de leitores; e por último, a proximidade com os sujeitos que liam (ouviam) suas crônicas, que também residia no canteiro a céu aberto que seria a futura capital.

A seguir, analisaremos algumas produções desse panorama de transformação e propagação das crônicas no Brasil com enfoque nos seguintes cronistas: Carlos Drummond de Andrade, Rachel de Queiroz, Rubem Braga, Sérgio Porto (ou Stanislaw Ponte Preta) e Clarisse Lispector. Assim sendo, se pretende com isso, comparar traços estilísticos desses cronistas, com os de Clemente Luz. 
Começaremos pelo mineiro Carlos Drummond de Andrade (1902-1987), cronista, também foi considerado o poeta brasileiro mais influente do século $X X$, suas crônicas são repletas de acontecimentos do cotidiano que encanta pela sua forma agradável e com muito lirismo, uma característica marcante também no estilo de Clemente Luz. Drummond trabalha bastante com o tempo, nas crônicas utiliza uma bela escrita cotidiana e subjetiva, no que destila do corrosivo. Para Arnaldo Nogueira Jr (s/d) o autor em Sentimento do mundo (1940), José (1942) e, sobretudo, em $A$ rosa do povo (1945), lançou-se ao encontro da chamada história contemporânea e, principalmente, da experiência coletiva, participando, solidarizando-se social e politicamente, descobrindo na luta a explicitação de sua mais íntima apreensão para com a vida como um todo.

Se observarmos as crônicas de Clemente Luz, serão vistos traços dessas mesmas características de Drummond, uma cintilante escrita do cotidiano da construção de Brasília, coisas subjetivas como o barro e a poeiras vermelha da cidade; ou o papel social, ao falar das dificuldades dos candangos de não possuir uma terra para morar no lugar onde construiu. Luz escreve inclusive, sobre grandes políticos como Israel Pinheiro, JK e Bernardo Sayão, associando-os aos sujeitos que apenas prestavam trabalhos braçais: os candangos. Clemente Luz revela, em entrevista ao ArPDF6 em 1996, que: “(...) já tinha publicado um livro, [e] já tinha recebido crítica e aplauso do Carlos Drummond de Andrade, do João Cabral de Mello $\mathrm{Neto}^{7}$, esse povo todo que tá aí na crista da onda. E já era um jornalista de bom trabalho (...)". (LUZ, 1996, p. 17).

Já a cearense Rachel de Queiroz (1920-2003), foi uma importante dramaturga, tradutora, escritora, jornalista e cronista política. É reconhecida também pelo fato de ter sido a primeira mulher a ingressar na Academia Brasileira de Letras. Durante as décadas de 1950 e 1960 escreveu alguns romances, crônicas e livros infanto-juvenis: o romance O Galo de Ouro (1950), a peça de teatro O Lampião (1953) e A Beata Maria do Egito (1958) o livro Cem

\footnotetext{
${ }^{6}$ Arquivo Público do Distrito Federal. Entrevista pertencente ao Programa de História Oral, 1996.

${ }^{7}$ Também citado por Clemente Luz, como na crista da onda de literatura, João Cabral de Melo Neto (19201999) foi um poeta e diplomata brasileiro. Notável pela produção de Morte e Vida Severina, poema dramático que o consagrou. Foi eleito membro da Academia Brasileira de Letras. Recebeu o Prêmio da Poesia, do Instituto Nacional do Livro, o Prêmio Jabuti da Academia Brasileira do Livro e o Prêmio da União Brasileira de Escritores, pelo livro Crime na Calle Relator (1987). Fonte: Projeto Releituras.
} 
Melhores Crônicas Escolhidas (1958), além das crônicas O Brasileiro Perplexo (1964) e O Caçador de Tatu (1967).

Na crônica "Brasília e a Rosa dos Ventos" (1988), presente no livro Obras reunidas (1989) da própria cronista; Rachel de Queiroz, externa uma crítica em relação à cidade, para ela a nova capital ficou longe dos centros populacionais do país, e consequentemente, de seus polos de civilização e cultura. Queiroz menciona que Brasília "ficou assim a mais de mil e muitos quilômetros das cidades capitais onde vive, trabalha, estuda, faz política a parte mais importante do povo brasileiro: Rio, São Paulo, Belo Horizonte, Salvador, Fortaleza, Recife, Porto Alegre, Curitiba, Manaus e todas mais". Para a autora, isso acarreta um desgaste dos homens públicos que são obrigados a fazer uso diário da ponte aérea. Assim sendo:

(...) os Ministros coitados, são eternos volantes viajadores, em deslocamentos frenéticos para todas as direções da rosa-dos-ventos. (...) E afinal esses homens precisam das suas horas de sono, de comer, beber, olhar o céu, a terra em redor, brincar com as crianças. Ler! Terão esquecido que também são de carne como nós. (QUEIROZ, 1989, p. 183).

Conforme Regma Maria dos santos (2009), Rachel de Queiroz apresenta em suas crônicas aspectos cotidianos, muitas vezes de sua vivência pessoal e coletiva, no qual também enfoca faces da política local ou nacional. As suas crônicas são, em geral, ligadas a fatos publicados na imprensa (como à Brasília, por exemplo), notícias que ouviu no rádio, comentários sobre o que se ouviu ou leu. Sendo assim, transita dos sentimentos mais íntimos aos sentimentos coletivos, extensivos também à política.

Na crônica "Os dois bonitos e os dois feios", presente no livro 100 Crônicas Escolhidas(1973) de de Rachel deQueiroz, a cronistaapresenta traços bem regionais, fazendo uma analogia do vaqueiro encourado com o cavaleiro medieval. Para a cronista, o traje é uma espécie de réplica em couro de uma armadura de cavaleiro. A crônica consiste numa disputa de um homem bonito com outro feio, antes amigos inseparáveis, por uma moça. Logo, um jura o outro de morte. O feio acaba morrendo e o bonito casa-se com a bela moça.

Rachel de Queiroz trabalha muitos regionalismos, e como mencionado faz uma analogia num espaço temporal longo. As características da cronista convergem para alguns traços encontrados nas crônicas de Clemente Luz em Invenção da cidade: aspectos cotidianos - muitas vezes de vivência pessoal-, linguagem simples e objetiva, além, é claro, dos personagens, que recebem uma atenção especial nas suas crônicas, já na maioria dos escritos da época esses sujeitos simples eram esquecidos e por vezes trocados pelos grandes 
personagens da construção de Brasília como Lúcio Costa, Oscar Niemeyer, Israel Pinheiro, Bernardo Sayão, entre outros.

Na crônica "Canto noturno", de Clemente Luz. Nela o cronista apresenta a importância das cantigas a noite para os trabalhadores nas obras, semelhantes às de um mutirão de roça, na qual se entoavam canções regionais. Para Luz (1967, p. 52), eram "cantos simples e profundos, talvez sem alegria, mas honesto e bravo. A noite traz o sono. [E] a luz elétrica entorpece um pouco a vista e os músculos". Os trabalhadores cantavam para não dormir e, consequentemente, para que o ritmo da construção não diminuísse no período noturno.

Outro contemporâneo de Clemente é o escritor e jornalista capixaba Rubem Braga (1913-1990), considerado por muitos o maior cronista brasileiro desde Machado de Assis. Tornou-se famoso como cronista de jornais e revistas de grande circulação no país. Escreveu suas primeiras crônicas em 1929, para o jornal Correio do Sul.

Um diferencial das suas crônicas é conseguir transformar o cotidiano numa grande poesia. Para Afrânio Coutinho (1986), uma cronista possui um estilo de dar pouco apreço aos fatos do mundo real e muitas vezes os escolhe como simples pretexto para a divagação pessoal, no qual é bem subjetivo e, dos escritores brasileiros, o mais lírico.

Assim sendo, é responsável por colocar o gênero nos melhores caminhos a partir da sua intersecção com o lirismo, próprio do fazer poético. Conforme Luciano Antônio (2013, p. 108):

\footnotetext{
Dentro da mescla de perspectivas, entram em jogo nas crônicas de Rubem Braga alguns aspectos da modalidade oral no texto escrito. A conversa entre cronista e leitor parece guiar-se não só pela leveza da linguagem como também pela fluidez no assunto comum ao texto oral. Desse modo, teríamos refletido na linguagem escrita o ritmo da oralidade, tornando a mensagem híbrida também neste aspecto.
}

Essa fluidez na qual o assunto se torna quase uma modalidade de texto oral, marca registrada dos textos de Rubem Braga, é muito semelhante aos de Clemente Luz, com diversas crônicas poéticas, aliado a um estilo próprio, carregado de lirismo. Este é provocado na maioria das vezes pelos acontecimentos cotidianos, pelas paisagens, pelos estados de alma, pelas pessoas, pela natureza, pelos sentimentos dos sujeitos que o cercam. Podemos observar esse estilo em Rubem Braga nas crônicas: "Meu ideal seria escrever", "Os amantes" e "Homem no mar", todas da década de 1950“Homem no mar" é uma crônica bem simples, porém de 
um lirismo impressionante. Nos perdemos na narrativa do cronista que observa da sua janela um homem nadando no mar, do qual não sabia nada: nome, cor, idade.

Lirismo semelhante encontra-se em várias crônicas de Clemente Luz, tais como: "Mala de madeira", em que o cronista demonstra como algo simples para muitos, pode ser muito simbólico para os candangos, tala qual uma mala de madeira. Já em "O caneco", Clemente Luz explica o respeito que se criara pelos canecos dos candangos e como era um desrespeito enorme colocar a boca no caneco dos outros, correndo o risco até paralisar uma obra; esse fato, aliado ao do candango sempre andar com o utensílio preso na cintura, revela um nãodito, como apresenta o cronista.

Cabe mencionar, Stanislaw Ponte Preta, conhecido pseudônimo de Sergio Porto (19231968), que foi cronista, escritor, radialista e compositor nascido no Rio de Janeiro. Com seu nome, Sergio Porto escreveu poucas obras de crônicas, podemos citar os livros: A Casa Demolida (1963) e As Cariocas (1967). Isso se deve ao fato de que na maioria de suas obras, o cronista utilizou seu pseudônimo, sendo algumas das obras: Tia Zulmira e Eu (1961), Primo Altamirando e Elas (1962), Rosamundo e os Outros (1963) e Garoto Linha Dura (1964).

De acordo com João Batista Ernesto de Moraes (1996), A criação da persona de Stanislaw Ponte Preta segue um processo singular, explicado pelo próprio Sérgio Porto no prefácio do primeiro livro de Stanislaw, Ti a Zulmira e Eu (1961):

De fato, Stanislaw Ponte Preta foi criado junto comigo e, praticamente, é meu irmão de criação. Moramos na mesma casa, tivemos a mesma infância e muitas vezes comemos no mesmo prato. Hoje, no entanto, embora vivendo ambos do jornalismo, já não somos tão ligados: raramente nos vemos, poucos são os nossos gostos comuns e acredito que seria uma temeridade da minha parte se continuasse companheiro fraterno do irrequieto autor deste livro, nas suas andanças e intemperanças por este mundo de Deus.(...) O leitor há de - por força - compreender o quanto é comprometedora, para um jornalista modesto e que tem esperanças de ser levado a sério, a companhia constante de amigo tão atrabiliário (PONTE PRETA, 1968, p. 8).

Assim sendo, o criador (Sérgio Porto) vem a público desvencilhar a sua imagem de sua criação (Ponte Preta) para que não surja, uma dúvida sequer, quanto à identidade de um e de outro, uma vez que:

Stanislaw é irrequieto, atrabiliário, irreverente; ao passo que Sérgio Porto é um 'jornalista modesto e que tem esperanças de ser levado a sério'. Poderíamos até dizer que temos aí o retrato e seu negativo que, apesar de serem um na essência, são dois na aparência. (MORAES, 1996, p. 125). 
O que podemos vislumbrar do modo de escrita de Stanislaw Ponte Preta nas crônicas de Clemente Luz é justamente a sátira ${ }^{8}$, seja uma sátira política ${ }^{9}$ ou uma sátira metonímia ${ }^{10}$, isto é, por meio do cômico, de fatos que causam horror, Ponte Preta consegue criticar determinadas situações vivenciadas no seu tempo.

E ainda assim, Stanislaw se utiliza de uma linguagem simples e objetiva. Como na crônica "A moça e a calça", presente em As cem melhores crônicas brasileiras (2007), na qual o cronista flagra uma situação em que uma moça é barrada na entrada do cinema por causa da roupa que estava usando, até que ela resolve de uma forma bem inteligente a situação de preconceito, quebrando com o discurso que barrava a sua entrada, o que torna cômica a história. Observamos essas sátiras em algumas crônicas de Clemente Luz em Invenção da cidade, como em "Figurinha difícil", na qual o cronista trata de uma febre na segunda metade década de 1950: os álbuns de figurinhas.

\begin{abstract}
Imaginemos que alguém de ideias luminosas resolva fazer uma divulgação diferente de Brasília. Imaginemos que organize um álbum de figurinhas, desses que andam por aí nas mãos da gente miúda e da gente grande também. $O$ álbum seria preenchido com fotos impressas em cores, fixando homens e cenas de Brasília. No álbum figurariam os maiorais, a começar por Juscelino, passando por Eleonora para terminar no candango simples e tranquilo. (LUZ, 1967, p. 124).
\end{abstract}

A crônica satírica critica o fato dos grandes expoentes em Brasília, estarem distantes o suficiente, para serem vistos por aqueles mais simples, os candangos, como os maiorais de Brasília. Nesse caso, a crítica é feita a uma política na qual começava a demonstrar uma divisão de classes nos canteiros de obras, onde poderíamos distinguir claramente os ditos maiorais e o que representavam para a cidade e, aqueles eram incumbidos de apenas prestar seus serviços braçais. Tudo isso exposto na crônica de de forma cômica e, acima de tudo, simples e objetiva.

Outra cronista de destaque no período foi Clarisse Lispector (1920-1977), natural de Tchelchenik na Ucrânia. Lispector publicou suas crônicas no Jornal do Brasil de agosto de 1967 a dezembro de 1973, mas a autora também produziu diversos romances como Perto do Coração Selvagem (1943), Uma Aprendizagem ou Livro dos Prazeres (1969), e Um Sopro de

\footnotetext{
${ }^{8}$ Segundo Hansen (1991 apud Moraes, 1996, p. 125) "a sátira é um subgênero do cômico como maledicência, ocupando-se de vícios que causam horror".

9 “A sátira política costuma florescer nos momentos em que há uma maior repressão política". (MORAES, 1996, p. 125).

${ }^{10}$ Conforme Moraes (1996) a sátira metonímica, consiste numa maneira encontrada por um cronista, no caso Stanislaw Ponte Preta, de atacar facetas do poder, o que acaba acarretando também, mesmo eu indiretamente, o poder central.
} 
Vida - Pulsações (1978); além de literatura infantil, novelas, teatro, entre outros. A maior parte das crônicas produzidas para o JB foi reunida, anos depois, nos livros $A$ descoberta do mundo (1984) e Aprendendo a viver (2004).

Conforme Nícea Nogueira (2007), Lispector estava inserida nos acontecimentos e nas tendências do seu momento histórico, ela narra na maioria das crônicas, episódios de seu cotidiano em primeira pessoa, onde assume, por diversas vezes, um tom confessional na sua escrita. Como em "Crônica social”, presente em A descoberta do mundo (1999) de Clarisse Lispectorem que revela o que acontece num almoço de senhoras que, como menciona a cronista, não deixaram de ser mulheres. A cronista apresenta desejos, conversas e, sobretudo, gafes. Desta forma, é notório que:

Clarice descreve em suas crônicas no Jornal do Brasil o papel que a mulher desempenhava na sociedade de sua época. Conhecer e desvendar seus mistérios permitia vislumbrar as particularidades femininas. Dentro da variedade de temas abordados nas crônicas, percebe-se que Clarice se importa em relatar o sentimento das mulheres em relação à opressão exercida sobre elas pela sociedade e ainda seu sentimento enquanto ser humano digno de liberdade. (NOGUEIRA, 2007, p. 92).

Luz não trabalha tanto o papel da mulher como Lispector em suas crônicas, contudo, narra episódios do cotidiano em primeira pessoa reunidas na Invenção da cidade, como em "Encontro Matinal" em que conversa com o Pequeno Príncipe, e acaba falando sobre a construção de Brasília. Assim como em "Cortina de barba", onde faz uma crítica sutil ao não reconhecimento daqueles que edificaram a cidade. Desta forma, conta que surgiu no bar uma ideia maluca para que os pioneiros se diferenciassem no dia 21 de abril daqueles que chegaram para tomar posse da cidade: deixar a barba crescer.

Cabe lembrar que Clarisse Lispector escreveu duas crônicas sobre a nova capital. Ambas estão reunidas no livro Para não esquecer (1999). Na primeira, intitulada "Brasília", a cronista confronta o projeto arquitetônico de Oscar Niemeyer à vida habitável, à cidade (des)humana, contestando um modelo urbano dominado pelo automóvel e pelo esteticismo. Já na segunda, "Brasília: Esplendor", vai nesse mesmo caminho, pois também diz respeito a impressões e julgamento desacreditado a respeito da nova capital do Brasil, por parte da cronista. Nas duas crônicas, Lispector externa suas impressões e perplexidade sobre a cidade que visitou nos anos de 1962 e 1974.

Clemente Luz possui uma diversidade no seu estilo como cronista, que é bem característico da transformação pela qual a crônica brasileira passava nos anos 1950 e 1960, 
com a contribuição desses importantes cronistas analisados. Em outras palavras, Clemente Luz parece compartilha traços estilísticos com diversos cronistas da época, que, como analisado, pode ter influenciado na construção de suas crônicas.

\section{Referências}

ANTONIO, Luciano. Rubem Braga: os itinerários de um cronista do Rio. Revista literária, Londrina, v. 11, p. 103-118, jul. 2013.

COUTINHO, Afrânio. Ensaio e crônica. In: (dir). A literatura no Brasil. Vol. 6, 3a Ed. rev. aum. Rio de Janeiro: José Olympio; Niterói: Ed. da UFF, 1986.

LISPECTOR, Clarice. A descoberta do mundo. Rio de Janeiro: Rocco, 1999. LUZ, Clemente. A invenção da cidade. Apresentação de Juscelino Kubitschek; prefácio de Israel Pinheiro. DF: Editora Horizonte - EBRASA, 1967.

Federal, 1996.

MARTINS, Ricardo André Ferreira. A crônica de Carlos Drummond de Andrade: visões e impressões sobre a sociedade, a cultura e o cotidiano brasileiro. RECORTE-revista eletrônica, UNINCOR, v. 10, n. 1, jan./jun. 2013.

MORAES. João Batista Ernesto de. O satírico nas crônicas de Stanislaw Ponte Preta. UNESP: Itinerários, Araraquara, n 10, 1996. p. 119-130.

NOGUEIRA, Nícea. A crônica de Clarice Lispector em diálogo com sua obra literária. Juiz de Fora: Revista VERBO DE MINAS: letras. V. 6 , n. 11/12, 2007. p. 87 - 99.

NOGUEIRA Jr, Arnaldo. Projeto releituras: Carlos Drummond de Andrade. Disponível em: http://www.releituras.com/drummond_bio.asp. Acesso em 02 de maio de 2017.

OLIVEIRA, Maria E. de; FREIRE, Manoel; CHAVES, Sérgio W. F. Rachel de Queiroz: uma mulher à frente do seu tempo. UNEB: produção de autoria feminina - Vol. 2, n. 1, jan/jun. 2012. p. 204-216.

PONTE PRETA, Stanislaw. Tia Zulmira e eu. Rio de Janeiro: Sabiá, 1968.

QUEIROZ, Rachel de. 100 Crônicas Escolhidas. Rio de Janeiro: José Olympio, 1973.

QUEIROZ, Rachel de. Obra Reunida. Vol.5. Rio de Janeiro: José Olympio, 1989.

REDMOND, William Valentine. Aspectos da crônica no Brasil: uma reflexão crítica. Juiz de Fora: CES/JF, v. 9, n. 17,. p.133 - 142, jan./jun. 2010.

SANTOS, Joaquim Ferreira dos (Org.). As cem melhores crônicas brasileiras. Rio de Janeiro: Objetiva, 2007. 
SANTOS, Regma Maria dos. Meios de comunicação e política nas crônicas de Rachel de Queiroz. ANPUH - XXV SIMPÓSIO NACIONAL DE HISTÓRIA - Fortaleza, 2009.

\section{Análise das crônicas de Invenção da cidade}

Clemente Luz possui um foco narrativo bem diversificado nas crônicas reunidas no seu livro Invenção da cidade. Suas crônicas possuem diversos personagens, situações na sua grande maioria cotidianas, com variadas formas de narrar a construção de uma nova cidade. Seus personagens variam conforme o enfoque e, sobretudo, os recursos literários que o cronista utiliza para despertar no seu interlocutor a mensagem proposta.

Devido a esta variedade, observamos a recorrência de três tipos de personagens: 1 ) temos muitas vezes uma narrativa em que o acontecimento é narrado como uma espécie de câmera, que descreve o ambiente e as situações; 2) por vezes, também, o cronista se apresenta como um personagem-testemunha que narra o evento, que participa de determinado acontecimento, como protagonista ou como um personagem auxiliar; 3) por último, também podemos observar nas crônicas o próprio escritor Clemente Luz revelando sua interioridade, seus sentimentos e suas expectativas.

As crônicas, do primeiro capítulo "Elementos", descrevem princípios significativos para cidade, em termos de expressão e "mitos" recorrentes nas narrativas dos construtores da cidade. Assim sendo, por meio de um foco narrativo que busca situações descritas pelo viés dos mais humildes, Clemente Luz detalha, por meio de uma narrativa semelhante a uma câmera: cenas, situações e grandes personagens desse período. Esse capítulo é o único com esse olhar voltado para apelidados de "maiorais", como em "O homem". Na narrativa o cronista vai traçando, por meio dos "dizeres" do povo, o perfil de um homem que é visto como mau, difícil, contundente e com uma grande responsabilidade, "carregada sobre seus ombros". Esse é Israel Pinheiro, o encarregado da difícil tarefa de construir uma cidade, que segundo o cronista:

Reuniu os primeiros voluntários da grande legião que deveria formar. Estabeleceu os primeiros postos de comando, recebeu do poder a indicação de nomes para os cargos de direção. E empreendeu a marcha rumo à Terra Assinalada... Pelos caminhos do céu e da terra, as caravanas avançaram, dia e noite, sob seu comando. Não teve de parar o sol, nem abrir o mar ao meio, 
para a vitória ou para o trânsito do povo. Mas teve que perder amigos e fazer inimigos. (LUZ, 1967, p. 30).

Nesta crônica, de uma forma simples e mediante a figura de Israel Pinheiro, Clemente Luz retrata o surgimento da Novacap ${ }^{11}$, o início da construção de Brasília, a chegada dos primeiros pioneiros, a construção das primeiras estradas, o primeiro alojamento... Ou seja, o início de tudo. Além disso, conforme o trecho acima, a crônica é carregada de um misticismo religioso, resultante da comparação da construção da nova capital com a Bíblica "A Terra Prometida"12, reforçada pela visão de Dom Bosco.

Além disso, Brasília contém muitos mitos relacionados à histórias dos primeiros dias de Brasília, muitos desses são a respeito da figura de outro grande expoente: o agrônomo Bernardo Sayão, como o cronista revela em "O mito". Na narrativa, Clemente Luz apresenta as "estórias" da criação da Cidade Livre, contadas em torno sua figura, como a da vinda para Brasília, a pedido do "Dotô Sayão", de uma família do município goiano de Ceres para ajudar a abrir estabelecimentos no atual Núcleo Bandeirante. Para o cronista:

E, de história em história, nó, que chegamos depois, fomos sentindo que um personagem se transformava em lenda, se transfigurava, à medida que Brasília tomava contornos de cidade. Era Bernardo Sayão, cuja história é a própria conquista do planalto e cuja estatura máscula mais parecia uma coluna sustentando os blocos de cimento e ferro do primeiro edifício da cidade. (LUZ, 1967, p. 34).

A figura personalista de Bernardo Sayão transformou-se mais ainda em lenda a partir da sua morte em janeiro de 1959 no Pará, onde abria na selva amazônica a rodovia BelémBrasília. No acidente que tirou a sua vida, que uma árvore caiu em cima da sua barraca, suscitando diversos mitos sobre o episódio. Muito querido pelos candangos, Sayão só não era mais popular entre os mais humildes e anônimos, do que Juscelino Kubitschek. Este, tem toda a sua interioridade infantil narrada em "O ritmo". Na crônica, Clemente Luz descreve uma festa oferecida pelos moradores da Cidade Livre ao então presidente, a festa de muito simples, tinha como grande atrativo um Circo e, claro, o carinho desses sujeitos:

\footnotetext{
${ }^{11}$ Companhia Urbanizadora da Nova Capital do Brasil - NOVACAP. Tinha como objetivo a administração das obras em Brasília, seu presidente era o político Israel Pinheiro.

12 Termo utilizado pela Bíblia para descrever a terra prometida ou dada por Deus, aos israelitas, descendentes dos patriarcas hebraicos Abraão, Isaque e Jacó.
} 
A festa era simples. Tão simples, que tinha até um espetáculo de Circo. Um tablado redondo, armado em frente ao palanque presidencial, deveria fazer vez de picadeiro. Redes desmontáveis, cordas, barras-móveis e outros aparelhos nômades como o próprio circo, formavam o conjunto pobre dos artistas pobres, mas fortes e sadios. (LUZ, 1967, p. 35).

Apesar do local e circunstâncias, o espetáculo era variado e divertiu a todos, sobretudo, o presidente, que relembrava, segundo Clemente Luz, os tempos de criança. A crônica além de explicitar esses sentimentos, faz alusão também aos "artistas pobres, mas fortes e sadios" do Circo (pincipalmente os das barras-moveis e do trapézio que carregam um esforço maior) com os construtores de Brasília. Já que ambos, se esforçam ao máximo para alcançar os objetivos propostos, e trabalham no chamado "ritmo de Brasília, incompressível para muitos.

Uma das situações narrativas mais marcantes das crônicas de Clemente Luz diz respeito ao cotidiano de trabalho nos canteiros de obras na construção de Brasília. Por ter como público leitor os Candangos, o cronista consegue com um lirismo sem igual, transformar situações simples em belas crônicas, como em "Canto Noturno". Narrado em primeira pessoa pelo pioneiro das letras brasilienses, essa crônica revela o canto simples e profundo dos trabalhadores nas obras no turno noturno. Nessa narrativa, Clemente Luz deixa transparecer também seu entusiasmo com obra:

Vocês podem imaginar o entusiasmo que senti, esta noite, quando as vozes, como num mutirão de roça, entoavam as canções regionais. Eram os nortistas, com os baiões ligeiros e sentimentais. Eram os mineiros, com as modinhas picantes e sentimentais, também. Como fundo musical poderoso, o ruído dos martelos, das serras, dos motores. E, quando a madrugada chegou, uma poderosa sirene determinou a suspensão do canto, como se fosse o sinal de recolher. Os ruídos desapareceram por completo, durante uma ou duas horas (...). (LUZ, 1967, p. 64).

Além disso, nessa ótica, Invenção da cidade possui várias crônicas que falam de coisas insignificantes para muitos, mas que Clemente Luz consegue demonstrar as suas grandezas e seus significados para o candango. Podemos citar as crônicas: "O mala-às-costas", "O caneco", "Pau-de-Arara", "Cartas"; contudo, de acordo com o próprio cronista nenhum desses é mais importante para um candango do que a mala de madeira.

Em "A mala de Madeira", Clemente Luz demonstra como um objeto tão simples se torna umas das coisas mais importante do retirante, especialmente do Norte ou do Nordeste. 
Assim sendo, enquanto não consegue emprego e aonde quer que vá, o candango a leva consigo. Os dois chegam a formar, inclusive, uma só figura na futura capital. Conforme a crônica:

A mala de madeira é a sua casa, é o seu mundo. Quando partiu, juntou o que tinha: roupas, alparcatas, algum dinheiro, embolou tudo com as esperanças de conquistar o sul do país, e desceu. A mala lhe serviu de banco, na hora do descanso ou da comida escassa e dosada; a mala lhe serviu de travesseiro, quando teve de recostar o corpo à sombra de uma árvore ou à beira de um rio, para recuperar um pouco das forças desgastadas... (LUZ, 1967, p. 71).

Além demonstrar a importância da mala de madeira para os candangos, essa crônica também traz uma diferença sutil de Clemente Luz em seus escritos. $O$ cronista, que começa narrando em primeira pessoa o seu ponto de vista sobre a importância das malas de madeira, acaba terminando sua crônica como uma câmera, que demonstra todo o simbolismo do objeto em um poema - de sua própria autoria. O cronista, dessa forma, constrói um cenário de sensibilidades e sentimentos desses trabalhadores, juntamente com sua mala, com relação às expectativas da construção de Brasília.

Além dos candangos, Clemente Luz traz em algumas crônicas a preocupação com o ambiente de "cidade de interior" presente na Cidade Livre e, sobretudo, nos acampamentos. O cronista fala dos "Redemoinhos", das "Andorinhas", da "Cidade Livre". Em "Animais estranhos", compara os sons da noite no interior com aqueles da paisagem noturna de Brasília, como observa em sua primeira semana no acampamento onde: “(...) A presença de cães ladrando indicava a anormalidade. Muita gente deve ter-se assustado, pois muita gente que aqui vive nunca viveu numa fazenda de criação de animais (...)". (LUZ, 1967, p. 105). Finalmente, depois de muito labutar, descobriu que os sons eram produzidos por um jumento que pastava ali perto, o que provocava o latido dos cães.

Aliás, o cronista dá uma atenção especial aos animais de Brasília. Em "Animais domésticos", Clemente Luz cita que esses animais têm a característica de um agrupamento de pessoas, porque diminuem a solidão e produzem diversos sons. Nessa crônica, Clemente afirma que, no início de Brasília, a Fundação da Casa Popular com quase 500 residências era triste, pois não havia famílias e, consequentemente, animais domésticos, contudo:

Vieram, aos poucos, as famílias. E com elas, veio o cão, veio o galo, vieram os pássaros domesticados em gaiolas. $E$, devagar, a pequena concentração de casas foi-se ordenando como um bairro habitado... As crianças saíam para as áreas fronteiras, onde existia apenas poeira, e brincavam com o seu cãozinho 
de estimação, ou rolavam com ele na terra e, depois, sujos, amarelos encardidos, voltavam para a casa. (LUZ, 1967, p. 57).

Dessa forma, Clemente Luz, mediante uma narrativa focada nos animais domésticos que alegravam o espírito de Brasília, revela a importância desses animais em uma sociedade.

O cronista demonstra o outro lado desse sentimento em "A cachorrinha morta"; nela a cachorrinha chamada por todos de "Planaltina" conquista os corações dos trabalhadores que Ihe dão amor e comida. Porém, numa certa manhã, a cachorrinha foi picada por uma cascavel, enchendo de tristeza o acampamento. De acordo com o cronista: “ (...) a vida, que era alegre, nos transmissores, ficou triste, porque a gente não escuta mais o latidinho alegre da bichinha, quando a gente vai chegando ou saindo... (LUZ, 1967, p. 79).

Como em "Animais domésticos", o autor também fala do cotidiano de crianças nas residências em Brasília. Clemente Luz procura sempre que possível falar das crianças da cidade, que, segundo ele, eram diferentes das do restante do país. Em "Batman, Robin Hood \& Cia", o cronista cita as crianças que brincam no grande espaço que Brasília possibilita e acompanham de perto a gestação da cidade. Nas brincadeiras, os super-heróis adquirem outras feições. Nessa narrativa, o autor se pergunta se Brasília não seria um sonho de Batman e Robin Hood:

Eu tenho a impressão de que todos os heróis dos tempos idos e dos tempos chegados, todos, se corporificaram, se transfiguraram em tratores, em escavadeiras, em guindastes, em arquitetos e engenheiros, e aqui estão erguendo a cidade, com a mesma facilidade com que o Capitão Marvel detém, no espaço, o voo supersônico de uma astronave de guerra marciana! (LUZ, 1967, p. 60).

Clemente Luz demonstra que, mesmo coisas já consagradas, como os heróis da Marvel, ganham uma reatualização em Brasília, devido ao ambiente vivenciado na construção da cidade. Outro exemplo de como as crianças de Brasília eram diferentes das do restante do país, pode ser constatada na crônica "Os olhos na vitrine", na qual um menino cobiça um brinquedo na vitrine de uma loja, na véspera de Natal em Brasília. O garoto cobiça não brinquedos comuns da idade deles, mas sim máquinas e automóveis que são vistos por ele diariamente na cidade em construção. O menino cobiça um Moto-Scrapper, poderosa máquina que abre valas e estradas, e também um jipe de brinquedo, pois: 
Um dia, será como o pai. Um dia constituirá casas e estradas, comandará máquinas de nomes complicados. Assim, o melhor, neste Natal de Brasília, é ganhar uma frota de máquinas e um jipe bem equipado, para construir, no quintal de sua casa, uma grande estrada que vá do tanque ao portão. (LUZ, 1967, p. 178).

Assim, para o cronista, o Natal de Brasília é diferente: possui novos cânticos e outras ambições. E o olhar simples das crianças demonstra claramente isso. Esse foco narrativo voltado para o que as crianças de Brasília vivem, deixa claro a variedade de situações narrativas utilizadas por Clemente Luz.

Aliás, esse olhar voltado para um cotidiano das crianças de Brasília, pode estar relacionado ao fato de que Clemente Luz trabalhou com a literatura infantil na década de 1940. Luz chegou a publicou entre outras obras: Bilino e Jaca, o mágico, 1944; Infância humilde de grandes homens, 1944; Aventura da bicharada, 1949; O caçador de mosquitos, 1953; Pedro Pipoca, 1957. Por conta dessa fase na Literatura Infantil, reconhecida na época, recebeu elogios do cartunista Ziraldo, que confessou ao relatar que lia os seus livros quando criança.

As crônicas de Invenção da cidade também apresentam uma preocupação relacionada às condições de alimentação, lazer e moradia. O cronista refere-se, por exemplo, à construção de moradia dos mais pobres em Brasília. Nessas construções qualquer material que vedasse o sol ou se antepusesse à chuva serviria, inclusive sacos de cimento. Na crônica "A casa de cimento", o cronista cita uma invasão chamada "Papelândia". Chega a ser cômica a história de um paraibano que juntou "sacos de cimento", construiu uma casa trabalhando firme e:

(...) Um mês depois, escreveu ao pai, dando-Ihe a notícia: estava construindo a casa, e, no fim do ano, daria um giro pela paraíba. E revelou no fim da carta: - "Já gastei duzentos sacos de cimento em minha casa...". O pai recebeu a carta e releu-a. levou-a aos amigos, que também leram a notícia alvissareira. Ninguém teve dúvida. O rapaz estava rico, pois quem pode gastar duzentos sacos de cimento para construir uma casa, é por que tem dinheiro sobrando... (LUZ, 1967, p. 82).

Porém, ao chegar em Brasília para ver a mansão do filho, o pai se deparou com uma a casa de "sacos de cimentos". Porém, como um bom paraibano, soube suportar o episódio. Destarte, a crônica se volta para um "problema" que crescia em Brasília: o surgimento das ditas "invasões", que abrigavam os desalojados da "capital da esperança". 
Nessa perspectiva, em "A casa flutuante", Clemente Luz fala, de uma forma crítica e sarcástica, dos pedidos de moradia que eram feitos ao presidente Juscelino Kubitschek ou ao presidente da Novacap Israel Pinheiro. No episódio, o cronista teve a ideia de pedir a JK um lote em Brasília. Contudo, esse lote se situaria na parte mais profunda do lago, na qual construiria, para quando as águas do lago subissem, uma casa flutuante onde ninguém poderia reclamar de ilegalidade, pois, se isso ocorresse, mandaria esvaziar o lago para mostrar por meio da escritura o local do lote que recebera do presidente legalmente. Com essa ideia "surreal", o cronista parece fazer uma analogia à Vila Amaury que acabou ficando submersa quando as águas do Paranoá encheram o lago artificial de Brasília; assim, os moradores dessa vila, também chamada de Vila Bananal, tiveram que deixar suas casas.

Por fim, outro ponto de vista explorado por Clemente Luz se refere ao que ele denomina de "ausentes", em outras palavras, aqueles sujeitos que não moravam em Brasília - por vários motivos -, mas que causavam uma série de sentimentos nos pioneiros que trabalhavam na cidade: angústia, saudade, solidão, ansiedade, preocupação, tristeza, entre outros.

Em "O pranto do homem", o cronista trata de uma forma onisciente neutra, isto é, fala em terceira pessoa, em que narra uma cena da revelação de um homem "semi-submerso" na saudade. Assim sendo, Clemente Luz descreve diversas situações que poderiam estar causando esse sentimento, fazendo as seguintes indagações: "saudade de quê? De quem?". Como narrador onisciente, revela o sentimento do personagem no final da história:

Uma noite, no bar, depois de dez horas, puxadas de serviço no escritório, viu o choro brotar nos olhos do boêmio. Era choro convulso, de saudade, de solidão. O boêmio lembrava-se da mãe, da noiva, que talvez perdesse pela distância e pela ausência de cartas... Outra noite - lembra-se bem - num dia de pagamento, encharcou-se de uísque, arrebentou as cadeias íntimas e saiu, rua afora, de braços abertos, gritando para a chuva... Chegou ao quarto completamente enlameado, mas feliz... (LUZ, 1967, p. 166).

A saudade era um dos sentimentos mais presentes em Brasília nesse período, que só diminuía com as notícias que às vezes demorava meses para chegar por meio de cartas, já que a comunicação de Brasília com o restante do país ainda não estava devidamente funcionando. Dessa forma, em "Mensagem dos ausentes", Clemente Luz (1967, p. 149) revela que: "os ausentes trazem o calor de seu carinho, através de cartas ou de mensagens transportadas por 
corações amigos. Mas as cartas não andam sozinhas... Precisam de uma série de medidas e providências, de um organismo funcionando (...)".

Para o cronista, Brasília carecia desse tal "organismo funcionando", o que causava angústia e sofrimento no coração daqueles que esperavam ansiosamente a mensagem de uma pessoa amada: uma noiva, a mãe, o pai, filhos... Pois as cartas não chegavam depressa à Brasília e o que se tinha era, sobretudo, muita espera e procura. $\mathrm{O}$ autor narra as histórias como uma espécie de câmera, dando ênfase aos detalhes, acima de tudo, de cunho sentimentais.

Posto isso, com essa variedade de pontos de vista, de situações narrativas, diferentes formas de narrar e apresentar seus personagens, Clemente Luz consegue juntar em Invenção da cidade uma gama de estórias do dia-a-dia da construção de Brasília, carregada de sensibilidade do período. Dessa forma, seu livro de crônicas focado na história dos mais humildes, apresenta na década de 1960 e ainda hoje, outra história da construção e transferência de Brasília.

\section{Referências}

LUZ, Clemente. A invenção da cidade. Apresentação de Juscelino Kubitschek; prefácio de Israel Pinheiro. Brasília: Editora Horizonte - EBRASA, 1967. 